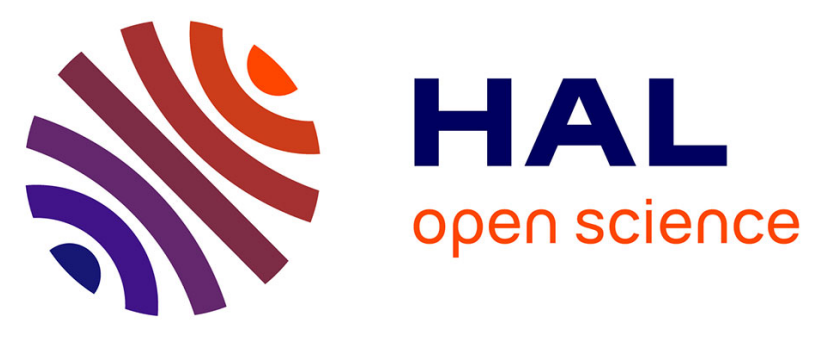

\title{
Use of Single-Metal Fragments for Cluster Building Synthesis, Structure, and Bonding of Heterometallaboranes
}

\author{
Bijan Mondal, Ranjit Bag, Thierry Roisnel, Sundargopal Ghosh
}

\section{- To cite this version:}

Bijan Mondal, Ranjit Bag, Thierry Roisnel, Sundargopal Ghosh. Use of Single-Metal Fragments for Cluster Building Synthesis, Structure, and Bonding of Heterometallaboranes. Inorganic Chemistry, 2019, 58 (4), pp.2744-2754. 10.1021/acs.inorgchem.8b03329 . hal-02050272

HAL Id: hal-02050272

https://hal-univ-rennes1.archives-ouvertes.fr/hal-02050272

Submitted on 22 Mar 2019

HAL is a multi-disciplinary open access archive for the deposit and dissemination of scientific research documents, whether they are published or not. The documents may come from teaching and research institutions in France or abroad, or from public or private research centers.
L'archive ouverte pluridisciplinaire HAL, est destinée au dépôt et à la diffusion de documents scientifiques de niveau recherche, publiés ou non, émanant des établissements d'enseignement et de recherche français ou étrangers, des laboratoires publics ou privés. 


\section{Use of Single Metal Fragments for Cluster Building: \\ Synthesis, Structure and Bonding of Heterometalla-}

\section{boranes}

Bijan Mondal ${ }^{\dagger}$, Ranjit Bag ${ }^{\dagger}$,Thierry Roisnel ${ }^{\ddagger}$ and Sundargopal Ghosh* ${ }^{\dagger}$

${ }^{\dagger}$ Department of Chemistry, Indian Institute of Technology Madras, Chennai 600 036, India.

${ }^{\ddagger}$ Institut des Sciences Chimiques de Rennes, UMR 6226 CNRS-Université de Rennes 1, F-35042

Rennes Cedex, France.

Fax: (+91) 442257 4202; Tel: (+91) 442257 4230; E-mail: sghosh@iitm.ac.in.

Keywords: metallaborane, diborane, cluster, tungsten and molybdenum 


\section{ABSTRACT}

Synergic property of the CO ligand in general can stabilize metal complexes at lower oxidation states. Utilizing this feature of CO ligand, we have recently isolated and structurally characterized a highly fluxional molybdenum complex $\left[\left\{\mathrm{Cp} * \mathrm{Mo}(\mathrm{CO})_{2}\right\}_{2}\left\{\mu-\eta^{2}: \eta^{2}-\mathrm{B}_{2} \mathrm{H}_{4}\right\}\right]\left(\mathrm{Cp}^{*}=\right.$ $\eta^{5}-\mathrm{C}_{5} \mathrm{Me}_{5}$ ) (2) comprising diborane(4) ligand. Compound 2 represents a rare class of bimetallic diborane(4) complex corresponding to a singly bridged Cs structure. In an attempt to isolate the tungsten analogue of $\mathbf{2}$, [\{Cp*W(CO $\left.\left.)_{2}\right\}_{2}\left\{\mu-\eta^{2}: \eta^{2}-\mathrm{B}_{2} \mathrm{H}_{4}\right\}\right]$, we have isolated an rare vertex-fused cluster $\left[(\mathrm{Cp} * \mathrm{~W})_{3} \mathrm{WB}_{9} \mathrm{H}_{18}\right](5)$. Having a structural alikeness with dimolybdenum alkyne complex [\{CpMo(CO $\left.\left.)_{2}\right\}_{2} \mathrm{C}_{2} \mathrm{H}_{2}\right]$, we have further explored the chemistry of $\mathbf{2}$ with $\mathrm{CO}$ gas that yielded homoleptic tri-molybdenum complex, $\left[(\mathrm{Cp} * \mathrm{Mo})_{3}(\mu-\mathrm{H})_{2}\left(\mu_{3}-\mathrm{H}\right)(\mu-\mathrm{CO})_{2} \mathrm{~B}_{4} \mathrm{H}_{4}\right](4)$. In an attempt to replace the 16 electron $\left\{\mathrm{Cp} * \mathrm{MoH}(\mathrm{CO})_{2}\right\}$ moiety in $\mathbf{4}$ with isolobal fragment $\left\{\mathrm{W}(\mathrm{CO})_{5}\right\}$, we treated the intermediate, obtained from the reaction of $\mathrm{Cp}^{*} \mathrm{MoCl}_{4}$ and $\mathrm{LiBH}_{4}$, with mono metal carbonyl fragment $\left\{\mathrm{W}(\mathrm{CO})_{5}\right.$.thf $\}$. The reaction indeed yielded two bimetallic clusters $\left[(\mathrm{Cp} * \mathrm{Mo})_{2} \mathrm{~B}_{4} \mathrm{H}_{8} \mathrm{~W}(\mathrm{CO})_{4}\right], 7$ and $\left[(\mathrm{Cp} * \mathrm{Mo})_{2} \mathrm{~B}_{4} \mathrm{H}_{6} \mathrm{~W}(\mathrm{CO})_{5}\right], 8$ that seem to have generated by the replacement of one $\{\mathrm{BH}\}$ or $\left\{\mathrm{BH}_{3}\right\}$ vertex from [(Cp*Mo $\left.)_{2} \mathrm{~B}_{5} \mathrm{H}_{9}\right]$ respectively. All of the compounds have been characterized by various spectroscopic analyses and single crystal X-ray diffraction studies. Electron counting rules and molecular orbital analyses provided further insight into the electronic structure of all these molecules.

\section{INTRODUCTION}

Boron hydrides i.e., boranes are an exceptionally diverse class ${ }^{1}$, which are of vast importance to many areas of chemistry, both from fundamental and application standpoint. ${ }^{2-4}$ Several research groups are actively involved on this, especially diboranes and its derivatives, primarily due to its mimic of alkane counterparts. ${ }^{5}$ The results not only enhance our understanding of chemical 
bonding $^{6-7}$ of $\mathrm{B}_{\mathrm{n}} \mathrm{H}_{\mathrm{n}+2}(\mathrm{n}=0,2,4)$ but also reveal their applications into homogeneous catalysis. ${ }^{8-9}$ The diboration reaction introduce boryl groups across the unsaturated organic species which offers valued synthetic routes. ${ }^{10-11}$ As a result, the diboration reaction turn out to be the mostused organometallic reaction in organic synthesis of bimetallic-diborane(4). ${ }^{12}$

Diborane(4) compounds have been utilized as relevant starting materials to generate electron precise metal-boron bonds. ${ }^{13}$ For example, borylene species of the type $\left[\left\{\mathrm{LMn}(\mathrm{CO})_{2}\right\}_{2} \mathrm{BR}\right](\mathrm{L}=$ $\eta^{5}-\mathrm{C}_{5} \mathrm{H}_{5}$ or $\eta^{5}-\mathrm{C}_{5} \mathrm{Me}_{5} ; \mathrm{R}={ }^{t} \mathrm{Bu}$ or $\mathrm{NMe}_{2}$ ) have been synthesised from diborane(4) reagents. ${ }^{14}$ Hydrogen substituted diborane compounds, particularly, bi- or tri-metallic diborane(4) compounds, are generally very rare. ${ }^{15}$ The derivatives of $\mathrm{B}_{2} \mathrm{H}_{6}$ as well as unsubstituted $\mathrm{B}_{2} \mathrm{H}_{6}$ are found to be stabilized by the metal fragments. ${ }^{16-17}$ Our recent findings of bimetallic diborane(4), $\left[\left\{\mathrm{Cp} * \mathrm{Mo}(\mathrm{CO})_{2}\right\}_{2}\left\{\mu-\eta^{2}: \eta^{2}-\mathrm{B}_{2} \mathrm{H}_{4}\right\}\right]$ (2) and diborene(2) species, [\{Cp*Mo(CO) $\left.\left.{ }_{2}\right\}_{2} \mathrm{~B}_{2} \mathrm{H}_{2} \mathrm{~W}(\mathrm{CO})_{4}\right]^{18}$ led us to explore the chemistry of $\mathbf{2}$ further, not only to increase the library but also to have substituted products within the realm of transition-metal borane chemistry.

The progress of metallaborane chemistry expanded significantly with the advancement of generalized synthetic route of group 4-9 metallaboranes. ${ }^{19-20}$ The electronic contributions of both metal and boranes in polyhedral metallaborane clusters are expressed differently than the individuals. ${ }^{21}$ As a result, this makes the metallaborane chemistry more versatile and it continues to surprise with the various structural types and unusual reactivities. ${ }^{22}$ Understanding the structures of such clusters required the early development of theories on chemical bonding, e.g. Wade-Mingos or Jemmis rules for electron counting. ${ }^{23,24}$ Herein, in this article, we report the syntheses and structural characterizations of various metallaborane clusters using CO ligands or mono metal carbonyl fragments, $\left[\mathrm{M}^{\prime}(\mathrm{CO})_{5} \cdot\right.$ thf $],\left(\mathrm{M}^{\prime}=\mathrm{Mo}\right.$ and $\left.\mathrm{W}\right)$. In addition, we have 
performed the theoretical calculations on the ground of density functional theory (DFT) to provide further insight into their bonding and electronic structures.

\section{RESULTS AND DISCUSSION}

The metallaborane clusters of early transition metals typically yielded uncommon problems that challenged the cluster electron counting rules. ${ }^{25}$ Therefore, as a part of our ongoing research on cluster growth chemistry, we intended to explore the metallaboranes of group-6 transition metals. ${ }^{18,26}$ As a result, we treated $\left[(\mathrm{Cp} * \mathrm{Mo})_{2}\left(\mu-\mathrm{Cl}_{2} \mathrm{~B}_{2} \mathrm{H}_{6}\right]^{27}\right.$ with $\mathrm{CO}$, which resulted in the formation of compounds $2,3^{28}$ and 4 (Scheme 1). A preliminary result of diborane(4) complex 2 has recently been reported. ${ }^{18}$ The detailed spectral and structural characterization of $\mathbf{2}$ and $\mathbf{4}$ is discussed below.
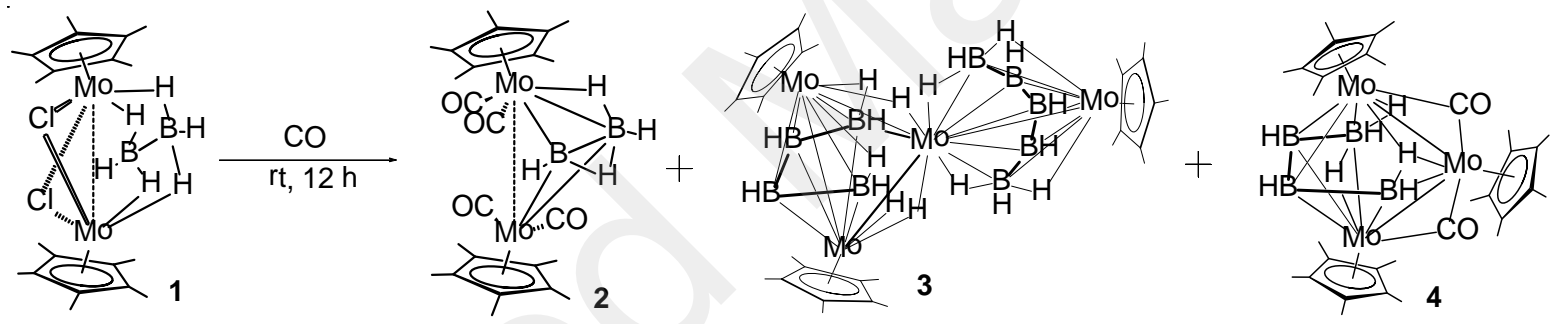

Scheme 1. Synthesis of molybdaborane clusters, 2-4.

[\{Cp*Mo(CO) $\left.\left.{ }_{2}\right\}_{2}\left\{\boldsymbol{\mu}-\boldsymbol{\eta}^{2}: \boldsymbol{\eta}^{2}-\mathrm{B}_{2} \mathrm{H}_{4}\right\}\right]$ (2): Reaction of $\left[(\mathrm{Cp} * \mathrm{Mo})_{2}(\mu-\mathrm{Cl})_{2} \mathrm{~B}_{2} \mathrm{H}_{6}\right]^{27}$ (1) at ambient temperature with $\mathrm{CO}$ gas produces 2 that has been characterized by ${ }^{11} \mathrm{~B},{ }^{1} \mathrm{H}$ and ${ }^{13} \mathrm{C}$ NMR, and IR. The mass spectrum and IR data of $\mathbf{2}$ suggests that it is a derivative of $\mathbf{1}$. Although, the room temperature ${ }^{11} \mathrm{~B}$ NMR was uninformative, at $-40{ }^{\circ} \mathrm{C}$ it showed two broad resonances appeared at $\delta=27.3$ and $-31.1 \mathrm{ppm}$, whereas the ${ }^{1} \mathrm{H}$ NMR showed three broad signals at $\delta=-11.3,-0.86$ and $3.28 \mathrm{ppm}$ along with the signal due to $\mathrm{Cp}^{*}$ ligands. 


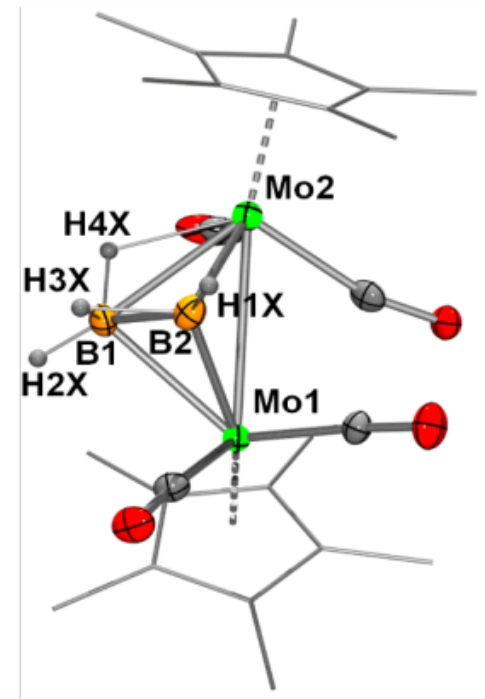

Figure 1. Molecular structure of 2 (hydrogen atoms on the $\mathrm{Cp}^{*}$ ligands are omitted for clarity).

Selected bond lengths ( $\AA$ ) and angles (deg): B1-B2 1.700(12), B1-Mo1 2.348(9), B1-Mo2 2.420(9), B2-Mo1 2.222(8), B2-Mo2 2.366(8), Mo1-Mo2 3.0617(8), B1-H2X 1.12(10), B1-H4X 1.13(7), B1-H3X 1.09(9), B2-H1X 1.25(11), B2-H3X 1.46(9), B2-B1-Mo2 67.5(4), Mo1-B1Mo2 79.9(3), B2-B1-H2X 139(5), Mo1-B1-H4X 115(4), Mo2-B1-H4X 47(4), H2X-B1-H4X 109(6), B2-B1-H3X 58(5), Mo1-B1-H3X 114(5), Mo2-B1-H3X 104(5), B1-B2-Mo1 72.2(4), B1-B2-Mo2 70.9(4), Mo1-B2-Mo2 83.7(3), B1-B2-H1X 155(5), Mo1-B2-H1X 128(5), Mo2-B2H1X 121(5), Mo1-B2-H3X 105(4), Mo2-B2-H3X 95(4), B2-Mo1-B1 43.6(3), B1-Mo1-Mo2 51.1(2), B2-Mo2-Mo1 46.1(2), B1-Mo2-Mo1 49.0(2).

In order to determine the solid-state structure of $\mathbf{2}$, the X-ray structure analysis was undertaken. The solid-state X-ray structure (Figure 1) can be seen as $\left[\left\{\mathrm{Cp} * \mathrm{Mo}(\mathrm{CO})_{2}\right\}_{2}\left\{\mu-\eta^{2}: \eta^{2}-\mathrm{B}_{2} \mathrm{H}_{4}\right\}\right]$. Most noteworthy feature of $\mathbf{2}$ is the presence of a $\left[\mathrm{B}_{2} \mathrm{H}_{4}\right]$ moiety that is linked between two $\left[\mathrm{Cp} * \mathrm{Mo}(\mathrm{CO})_{2}\right]$ moieties such that the B-B bond positions perpendicular to the Mo-Mo bond. The B-B bond distance of 1.700(12) $\AA$ in 2 is significantly shorter as compared to the base stabilized diborane(4) complexes, for example, [( $\left.\left.\mathrm{PMe}_{3}\right)_{2} \mathrm{~B}_{2} \mathrm{H}_{4} \mathrm{ZnCl}_{2}\right]$ (1.814(6) $\left.\AA\right)$, [( $\left.\left(\mathrm{PMe}_{3}\right)_{2} \mathrm{~B}_{2} \mathrm{H}_{4} \mathrm{Cr}(\mathrm{CO})_{4}\right]$ 
$(1.748(11) \AA)$ and $\left[\left(\mathrm{PMe}_{3}\right)_{2} \mathrm{~B}_{2} \mathrm{H}_{4} \mathrm{~W}(\mathrm{CO})_{4}\right](1.74(41) \AA) .{ }^{29}$ The Mo-Mo bond distance of 3.0617(8) $\AA$ is consistent with single bond order which is comparable to those of $\left[\left\{\mathrm{CpMo}(\mathrm{CO})_{2}\right\}_{2}\left\{\mu-\eta^{2}: \eta^{2}-\mathrm{C}_{2} \mathrm{R}_{2}\right\}\right](\mathrm{R}=\mathrm{H} / \mathrm{Et} / \mathrm{Ph})\left(\right.$ avg. 2.971(1) $\AA$ ) and $\left[\left\{\mathrm{CpMo}(\mathrm{CO})_{2}\right\}_{2}\left\{\mu-\eta^{2}: \eta^{2}-\right.\right.$ $\left.\left.\mathrm{P}_{2}\right\}\right]$ (3.022(1) $\left.\AA\right) .{ }^{30}$ Among the different isomers of diborane(4), the singly bridged isomer with $C_{s}$ symmetry is very rare and beside 2 the only such example hypothesised is $\left[\mathrm{Co}_{2}(\mathrm{CO})_{6} \mathrm{~B}_{2} \mathrm{H}_{4}\right] .{ }^{31}$

Although the Cp-Mo-Mo-Cp axis in $\left[\left\{\mathrm{CpMo}(\mathrm{CO})_{2}\right\}_{2}\right]$ is nearly linear, the structures of both $\left[\left\{\mathrm{CpMo}(\mathrm{CO})_{2}\right\}_{2}\left\{\mu-\eta^{2}: \eta^{2}-\mathrm{C}_{2} \mathrm{H}_{2}\right\}\right]$ and 2 show distinct Mo-Mo-(Cp/Cp*) angles (Chart 1). The dihedral angle of $\mathrm{Cp} / \mathrm{Cp} *-\mathrm{M}-\mathrm{M}-\mathrm{Cp} / \mathrm{Cp}^{*}\left(147.6^{\circ}\right.$ vs $160.3^{\circ}$, see Chart 1$)$ is related to the $\mathrm{Cp} / \mathrm{Cp}$ *-M-M angle. The longer distance of $\mathrm{B}-\mathrm{B}$ in comparison to that of $\mathrm{C}-\mathrm{C}$ would require a more diffuse orbitals on the $\mathrm{Cp} * \mathrm{M}-\mathrm{M}-\mathrm{Cp}^{*}$ in 2 . This can be achieved by bending the $\mathrm{Cp}^{*} \mathrm{~s}$ farther away from the Mo-Mo axis, i.e. Cp*-M-M angle has to decrease. However, this decrease brings the two $\mathrm{Cp}^{*}$ s together. The molecule reduces the $\mathrm{Cp}^{*}---\mathrm{Cp} *$ non-bonding interactions by increasing the $\mathrm{Cp}^{*}-\mathrm{M}-\mathrm{M}-\mathrm{Cp} *$ dihedral angle. The opening of this angle and the positioning of the carbonyls and $\mathrm{Cp}^{*}$ rings over Mo-Mo bond results from the longer B-B distance (in relation to $\mathrm{C}-\mathrm{C}$ ) that requires a rehybridization at the metal centre for better Mo-B bonding.
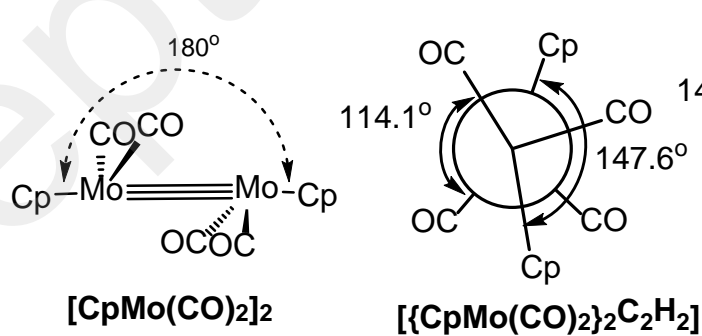

$\left[\left\{\mathrm{CpMo}(\mathrm{CO})_{2}\right\}_{2} \mathrm{C}_{2} \mathrm{H}_{2}\right]$

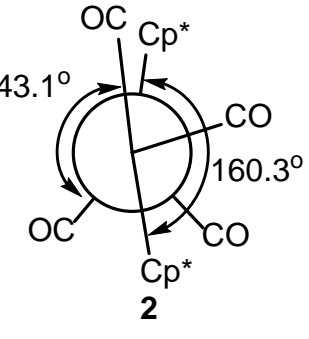

Chart 1. Schematic representation of the dihedral angles of $\mathrm{Cp}^{\prime} \cdots \mathrm{Mo}-\mathrm{M} \cdots \mathrm{Cp}$ in $\left[\mathrm{CpMo}(\mathrm{CO})_{2}\right]_{2}$, $\left[\left\{\mathrm{CpMo}(\mathrm{CO})_{2}\right\}_{2} \mathrm{C}_{2} \mathrm{H}_{2}\right]$ and $2\left(\mathrm{Cp}=\mathrm{Cp}\right.$ or $\left.\mathrm{Cp}^{*}\right)$. 
Electron counting rules along with isolobal analogy suggest a close resemblance of $\mathbf{2}^{32}$ with $\left[\left\{\mathrm{CpMo}(\mathrm{CO})_{2}\right\}_{2}\left\{\mu-\eta^{2}: \eta^{2}-\mathrm{C}_{2} \mathrm{H}_{2}\right\}\right]$. Thus, compound 2 is a true mimic of Cotton's dimolybdenum alkyne complexes, $\left[\left\{\mathrm{CpMo}(\mathrm{CO})_{2}\right\}_{2}\left\{\mu-\eta^{2}: \eta^{2}-\mathrm{C}_{2} \mathrm{R}_{2}\right\}\right](\mathrm{R}=\mathrm{H} / \mathrm{Et} / \mathrm{Ph}){ }^{30 a}$ This further reveals that the $\left[\mathrm{B}_{2} \mathrm{H}_{4}\right]$ fragment apparently binds with the fragment $\left[\mathrm{Cp} * \mathrm{Mo}(\mathrm{CO})_{2}\right]_{2}$ (16 electron at each metal center) through four-electrons so that each Mo atom attain the 18 electron count, which is vitually similar to the bonding of RC $\equiv \mathrm{CR}$ in $\left[\left\{\mathrm{CpMo}(\mathrm{CO})_{2}\right\}_{2}\left\{\mu-\eta^{2}: \eta^{2}-\mathrm{C}_{2} \mathrm{R}_{2}\right\}\right]$. On the other hand, adding 6 skeletal electron fragment $\mathrm{B}_{2} \mathrm{H}_{4}(2 \mathrm{BH}+2 \mathrm{H})$ to two $\left\{\mathrm{CpMo}(\mathrm{CO})_{2}\right\}$ moieties (6 skeletal electron) makes a total of 12 skeletal electrons or 6 skeletal electron pairs (seps). ${ }^{23,33}$ This leads to a nido geometry and makes compound 2 isoelectronic to $\left[\left\{\mathrm{CpMo}(\mathrm{CO})_{2}\right\}_{2}\left\{\mu-\eta^{2}: \eta^{2}-\mathrm{C}_{2} \mathrm{R}_{2}\right\}\right]$.

Homoleptic cluster, $\left[\left(C p^{*} M o\right)_{3}(\mu-H)_{2}\left(\mu_{3}-\mathrm{H}\right)(\mu-C O)_{2} B_{4} H_{4}\right](4)$ : Compound 4 was isolated as a brown solid in $10 \%$ yield. The mass spectrum of 4 showed a molecular ion peak at $\mathrm{m} / \mathrm{z} 807$. The IR spectra showed strong absorption bands at 1787 and $1729 \mathrm{~cm}^{-1}$ corresponding to bridging CO ligands. The ${ }^{1} \mathrm{H}$ NMR displayed two signals at $\delta=1.95$ and $1.91 \mathrm{ppm}$ in $1: 2$ ratio that rationalizes the presence of two different types of $\mathrm{Cp}^{*}$ ligands. This implies two chemically dissimilar Mo environments. The presence of $\mathrm{Cp}^{*}$ and $\mathrm{CO}$ ligands have also been supported by ${ }^{13} \mathrm{C}$ NMR. In addition, the ${ }^{1} \mathrm{H}$ NMR shows three resonances in the upfield region at $\delta=-13.17$, 9.35 and -8.85 in 1:1:1 ratios, which may be due to the presence of bridged Mo-H-Mo and MoH-B protons. The ${ }^{11} \mathrm{~B}\left\{{ }^{1} \mathrm{H}\right\}$ NMR spectrum shows four resonances at $\delta=88.3,83.2,46.3$ and $23.5 \mathrm{ppm}$ in 1:1:1:1 ratio, which demonstrates the presence of four dissimilar boron atoms in $\mathbf{4}$. However, identity of the molecule was unambiguous and definitive structural characterization was determined by X-ray diffraction analysis on a suitable crystal obtained from a solution of compound 4 in hexane- $\mathrm{CH}_{2} \mathrm{Cl}_{2}$ solvent mixture at $-10{ }^{\circ} \mathrm{C}$. 


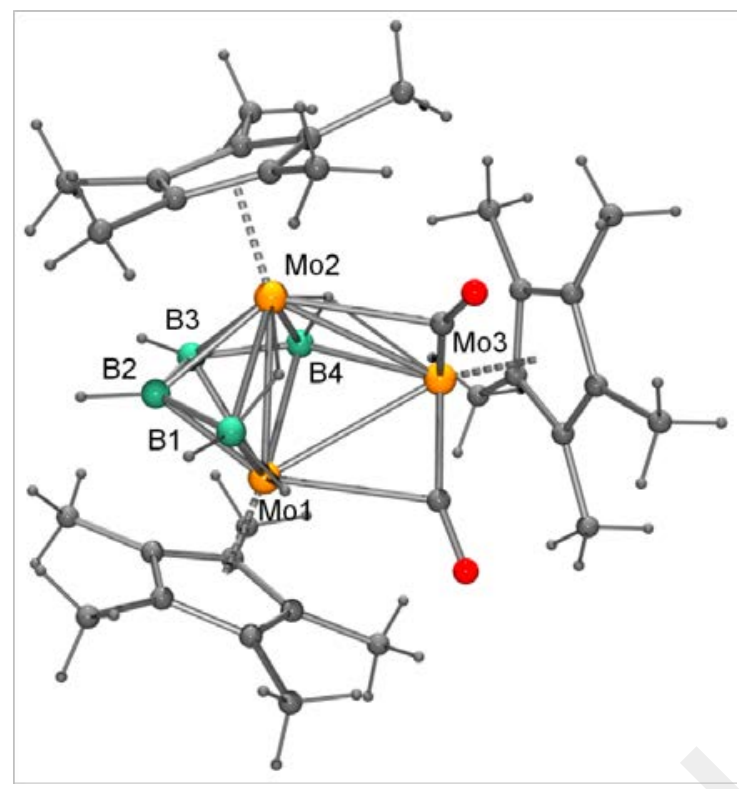

Figure 2. Molecular structure and labeling diagram for 4. Selected bond lengths $(\AA)$ and bond angles ( ${ }^{\circ}$ ): Mo1-Mo2 2.8338(5), Mo2-Mo3 2.9843(5), B1-B2 1.731(8), B2-B3 1.713(8), B3-B4 1.708(7), B1-Mo1 2.305(6), B1-Mo2 2.307(6), B2-Mo2 2.180(5), B2-Mo1 2.205(5), B4-Mo2 2.277(6), B4-Mo1 2.342(5), Mo1-Mo2-Mo3 61.479(13), Mo2-Mo1-Mo3 61.752(13), Mo1-Mo3Mo2 56.769(12).

The molecular structure of $\mathbf{4}$, shown in Figure 2, can be seen as $\left[(\mathrm{Cp} * \mathrm{Mo})_{3}(\mu-\mathrm{H})_{2}\left(\mu_{3^{-}}\right.\right.$ $\left.\mathrm{H})(\mu-\mathrm{CO})_{2} \mathrm{~B}_{4} \mathrm{H}_{4}\right]$ which is fully consistent with the solution spectroscopic data. The polyhedral skeletal electron pair theory (PSEPT) $)^{23,33}$ showed that compound $\mathbf{4}$ can be viewed as 6 sep (skeletal electron pair) oblato-nido hexagonal bipyramidal cluster. As a result, the core geometry appears to be similar to $\left[(\mathrm{Cp} * \mathrm{Mo})_{2} \mathrm{~B}_{5} \mathrm{H}_{9}\right](\mathbf{I})^{34}$ where one of the $\left\{\mathrm{BH}_{2}\right\}$ vertices in the open face has been replaced by isoelectronic fragment $\left\{\mathrm{Cp} * \mathrm{Mo}(\mathrm{CO})_{2}\right\}$. This resulted in a small stabilization of the LUMO but destabilization of the HOMO as compared to I (Table 1). Note that all the three Mo-Mo bond distances are dissimilar in 4. Although, the axial Mo1-Mo2 distance is similar to that of $\mathbf{I}$ (2.833 vs $2.81 \AA$ ), the peripheral Mo-Mo distances are significantly 
longer (3.004 and $2.946 \AA$ ). This has also been reflected in the WBI (Wiberg bond index) values; for example, WBI of Mo1-Mo2 (0.73) is ca. 1.5 times greater then the other Mo-Mo bonds (Mo2-Mo3: 0.39 and Mo1-Mo3: 0.51). The MO analyses of 4' (a Cp analogue of 4) show that both the HOMO and HOMO-1 (Figures 3b-c and S21) mostly involves Mo-Mo bonding. Further, to gain some insights into the Mo-Mo interactions in 4' we have carried out the NBO analysis. The NLMOs clearly demonstrate the Mo-Mo interactions (Figures 3a and S22). The molecular graph, Laplacian plot of electron density and WBI values indicate that the CO ligands are closer to Mo3 that can also be seen from the X-ray structure analyses.

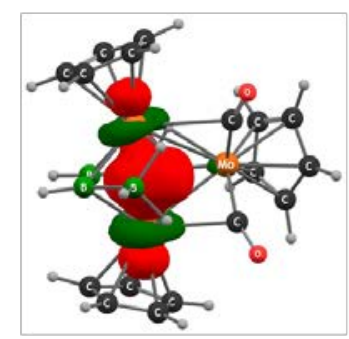

(a)

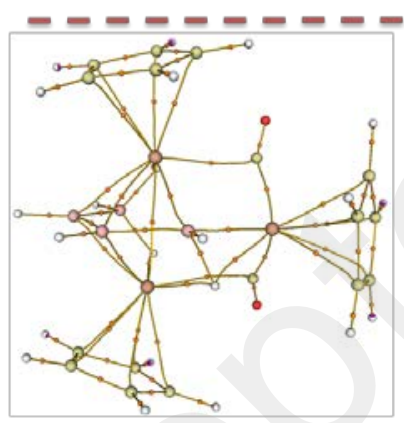

(e)

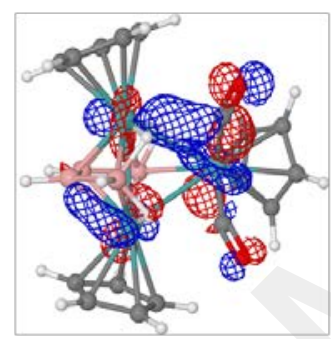

(b)

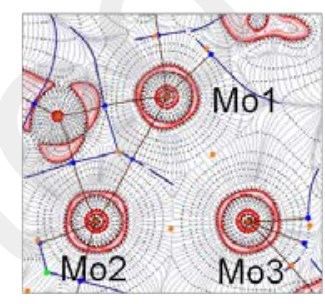

(f)

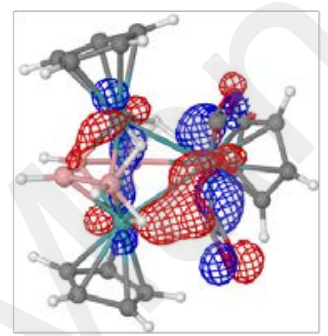

(c)

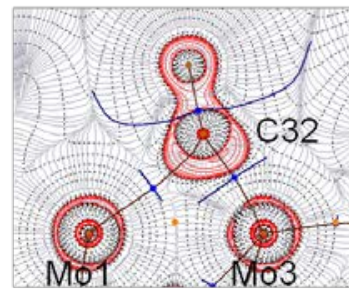

(g)

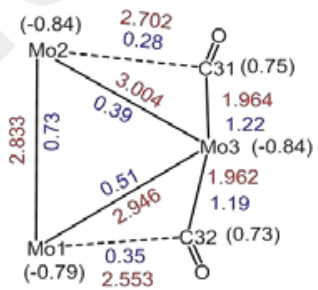

(d)

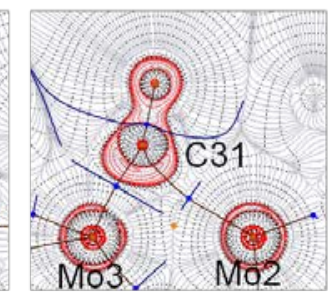

(h)

Figure 3. Investigating the Mo-Mobonding in 4'. (a) natural localized molecular orbital (NLMO) obtained from NBO analysis, (b) HOMO, (c) HOMO-1, (d) The $\mathrm{Mo}_{3}$-core (WBIs are shown in blue, bond distances in red and natural charges in parenthesis), (e) molecular graphs for the model 1', contour line diagrams of the Laplacian of electron density inMos plane (f) and Mo-CMoplanes (g-h) [Solid red lines indicate areas of charge concentration $\left(\nabla^{2} \rho(r)<0\right)$, while dashed black lines show areas of charge depletion $\left.\left(\nabla^{2} \rho(r)>0\right)\right]$. 
Table 1. DFT calculated energies of the HOMO and LUMO (eV), HOMO-LUMO gaps ( $\triangle \mathrm{E}=$ $\left.\mathrm{E}_{\mathrm{LUMO}}-\mathrm{E}_{\text {Hомо }}, \mathrm{eV}\right)$ of $\left[(\mathrm{CpM})_{2} \mathrm{~B}_{5} \mathrm{H}_{9}\right]\left(\mathrm{M}=\mathrm{Mo}\left(\mathrm{I}^{\prime}\right)\right.$ and $\left.\mathrm{W}(\mathrm{II})\right), 3^{\prime}-5 ', 7^{\prime}$ and $\mathbf{8}^{\prime}$.

\begin{tabular}{llllllll}
\hline & $\mathbf{I}^{\prime}$ & $\mathbf{I I}^{\prime}$ & $\mathbf{3}^{\prime}$ & $\mathbf{4}^{\prime}$ & $\mathbf{5}^{\prime}$ & $\mathbf{7}^{\prime}$ & $\mathbf{8}^{\prime}$ \\
\hline HOMO & -4.40 & -4.84 & -4.99 & -4.60 & -4.84 & -5.07 & -3.52 \\
LUMO & -1.32 & -1.44 & -3.25 & -3.19 & -2.99 & -3.63 & -1.10 \\
$\Delta \mathrm{E}$ & 3.08 & 3.40 & 1.74 & 1.41 & 1.85 & 1.44 & 2.42 \\
\hline
\end{tabular}

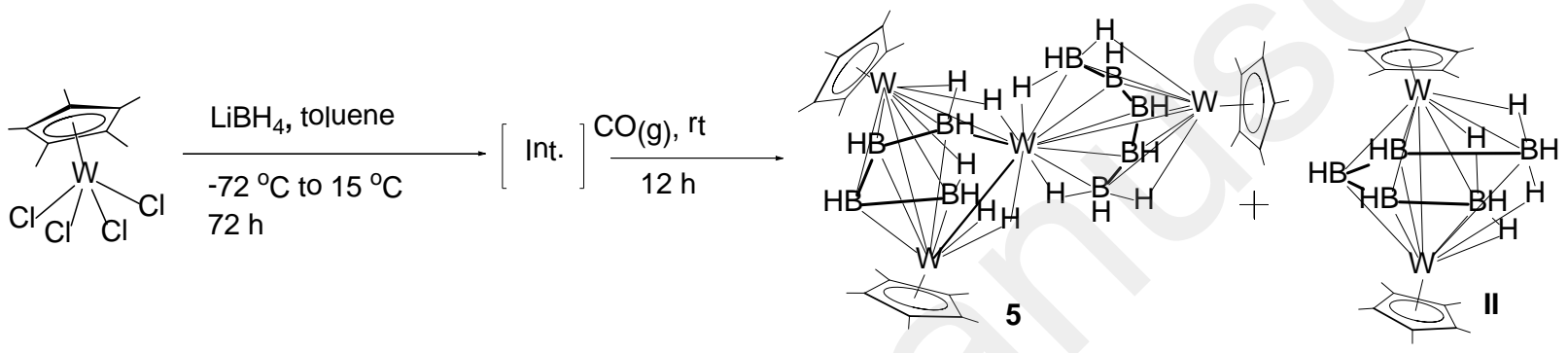

Scheme 2. Synthesis of tungstaborane cluster, 5.

[(Cp*M) $\left.)_{3} \mathbf{M B}_{9} \mathbf{H}_{18}\right]$ [M= Mo (3), W (5)]: Isolation and structural characterization of diborane(4) molybdenum complex 2 led us to explore the chemistry of tungsten system mainly with an objective to isolate the analogue of $2,\left\{\mathrm{Cp} * \mathrm{~W}(\mathrm{CO})_{2}\right\}_{2} \mathrm{~B}_{2} \mathrm{H}_{4}$. Although the objective of isolating analogous 2 was not achieved, we have isolated a vertex-fused tungsten cluster $\left[(\mathrm{Cp} * \mathrm{~W})_{3} \mathrm{WB}_{9} \mathrm{H}_{18}\right]$ (5). Compound 5 was isolated as a byproduct in parallel to the formation of $\left[(\mathrm{Cp} * \mathrm{~W})_{2} \mathrm{~B}_{5} \mathrm{H}_{9}\right] \quad(\mathbf{I I}) .^{35}$ These compounds can be separated by preparative thin-layer chromatography (TLC), allowing the characterization of pure $\mathbf{5}$. The mass spectrum of $\mathbf{5}$ showed a molecular ion peak $[\mathrm{m} / \mathrm{z}]$ corresponding to $\mathrm{C}_{30} \mathrm{H}_{63} \mathrm{~W}_{4} \mathrm{~B}_{9}$, while the IR spectrum confirms the absence of CO ligands. The ${ }^{11} \mathrm{~B}\left\{{ }^{1} \mathrm{H}\right\}$ NMR spectrum displayed a set of nine resonances between $\delta=55.3$ and $21.9 \mathrm{ppm}$ (from high frequency to low frequency), distributed over a chemical shift range of $c a .30 \mathrm{ppm}^{36}$ Besides the BH terminal protons, the ${ }^{1} \mathrm{H}$ NMR showed highly shielded upfield resonances which may be due to the presence of bridging $\mathrm{W}-\mathrm{H}-\mathrm{B}$ protons. In addition, 
the ${ }^{1} \mathrm{H}$ and ${ }^{13} \mathrm{C}$ NMR spectra of 5 are in consistent with the existence of two chemically different Cp* ligands.

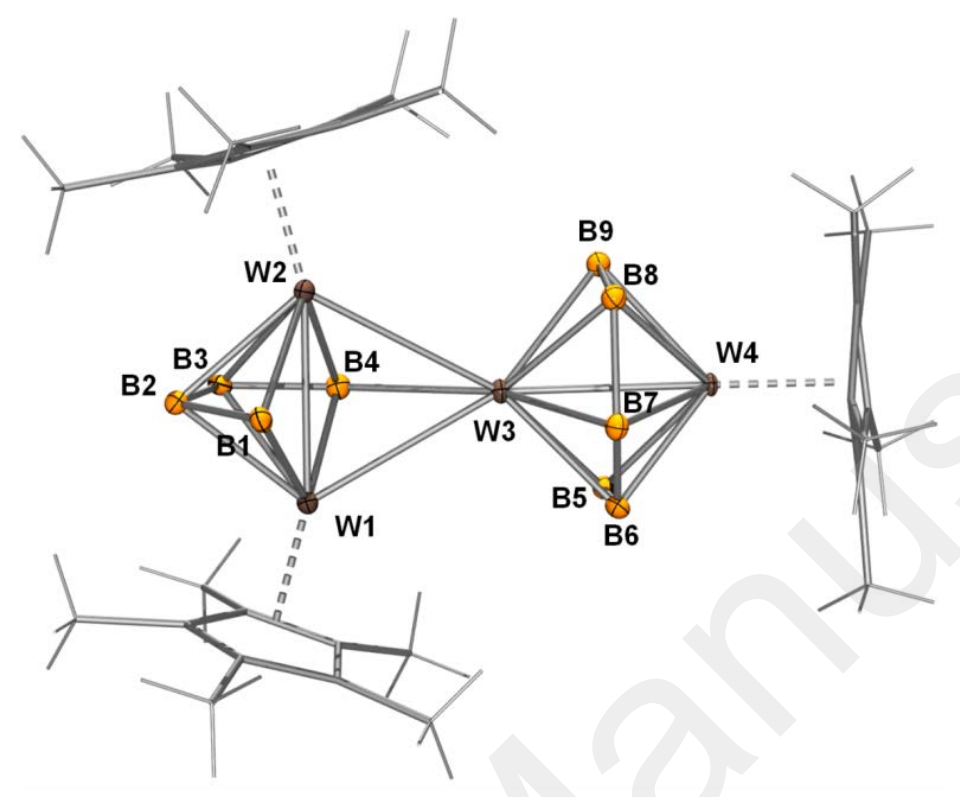

Figure 4. Molecular structure of 5. Ellipsoids are set at 30\% probability (hydrogen atoms on the Cp* ligands are omitted for clarity) Selected bond lengths ( $\AA$ ) and bond angles (degree).: W1W2 2.839(2), W1-W3 3.013(2), W3-W4 2.856(2), W2-W3 3.046(2), W1-B1 2.258(4), W1-B4 2.6181(5), B1-B2 1 699(6), B2-B3 1.760(6), B8-B9 1.838(8), B7-B8 1.770(8), W1-W3-W2 55.8(5), W1-W2-W3 61.4(5), W2-W1-W3 62.6(5), W1-B1-W2 77.1(13), B1-B2-B3 120.0(3).

The single crystal X-ray structure analysis was performed on a brown crystal of $\mathbf{5}$ that was obtained from the concentrated hexane solution at $-4{ }^{\circ} \mathrm{C}$. As shown in Figure 4 , the molecular structure of $\mathbf{5}$ can be viewed as a fusion of two clusters through a common single atom vertex. The X-ray structure and the solution state spectroscopic data are consistent with the molybdenum analogue, $\left[(\mathrm{Cp} * \mathrm{Mo})_{3} \mathrm{MoB}_{9} \mathrm{H}_{18}\right](3) .{ }^{28}$ Although, all the hydrogen atoms were not located in the X-ray diffraction study, evidence for their presence has been unequivocally supported by ${ }^{1} \mathrm{H}$ NMR spectroscopy. Core structure of $\mathbf{5}$ is composed of two independent 
clusters, oblato-nido $\left\{\mathrm{W}_{2} \mathrm{~B}_{5}\right\}$ and oblato-arachno $\left\{\mathrm{W}_{2} \mathrm{~B}_{4}\right\}$ hexagonal bipyramid clusters fused in perpendicular fashion through a naked tungsten atom (W3). The dihedral angle between the basal planes of the corresponding $\mathrm{B}_{5}$ - and $\mathrm{B}_{4}$ - belts is $85.53^{\circ}$. This brings six $\mathrm{B}$ atoms and four hydride ligands in the coordination sphere of W3 in expense of a $\mathrm{Cp}^{*}$ ligand of compound II. Both the cluster fragments and their structural parameters resemble with those of II. However, the solid state X-ray structure reveals two different sets of W-W bond lengths [W1-W2: 2.839(2), W3-W4 (2.856(2) $\AA$ and W1-W3: 3.013(2), W2-W3: 3.046(2) $\AA$ ] with the average W-B and B-B bond distances comparable with the reported tungstaborane compounds (Table 2). Longer W-W bond lengths may be attributed to the unique chemical environment of the naked W3. This observation is in line with the Laplacian plot (Figure 5b) as well as ELF plot (Figure 5c), as both the diagrams reveal high electron density concentration along W1-W2 bond than W1-W3 and W2W3. Similar bonding situation has been observed in $\left[\left\{1-(\mathrm{Cp} * \mathrm{Ru})(\mu-\mathrm{H}) \mathrm{B}_{4} \mathrm{H}_{9}\right\}_{2} \mathrm{Ru}\right]$ that showed shorter metal-metal bond distance compared to $\left[1,2-(\mathrm{Cp} * \mathrm{Ru})_{2}(\mu-\mathrm{H}) \mathrm{B}_{4} \mathrm{H}_{9}\right] .{ }^{37}$ The only difference between 3 and 5 is their ${ }^{11} \mathrm{~B}$ NMR chemical shifts. The ${ }^{11} \mathrm{~B}$ resonances of 5 appeared at upfield region as compared to 3 . This can well be understood from the fact that more charge accumulation occurred over B centers in $\mathbf{5}$ compare to $\mathbf{3}$ (Figure 5e).
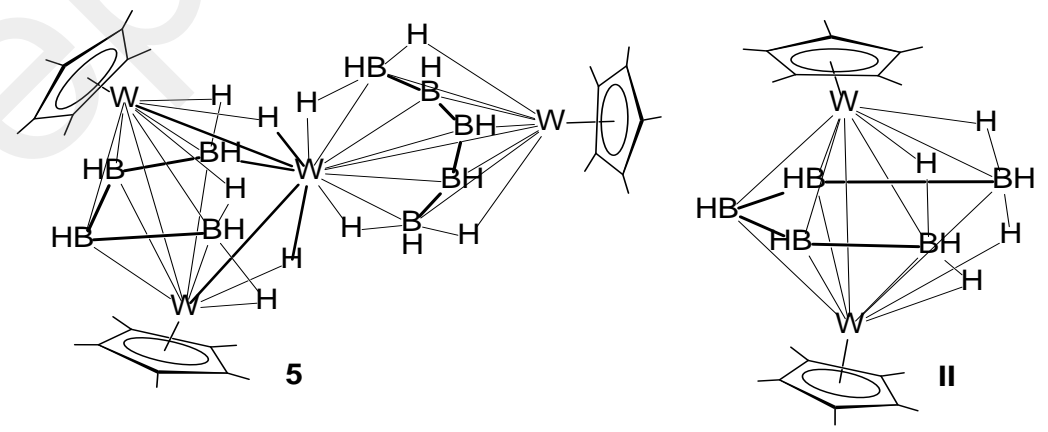

Chart 2. Structural equivalence of 5 with (II). 
The 18-electron count rule for $\mathbf{5}$ becomes more apparent when one considers that the $\mathrm{W}$ atom in $\left[(\mathrm{Cp} * \mathrm{~W})_{2} \mathrm{~B}_{5} \mathrm{H}_{9}\right]$ (II, Chart 2) receives five electrons from the $\mathrm{Cp}^{*}$ ligand. This is comparable to a case in which $\left\{(\mathrm{Cp} * \mathrm{~W})_{2} \mathrm{~B}_{4} \mathrm{H}_{9}\right\}$ fragment in $\mathbf{5}$ contributes five electron to the bare tungsten atom (W3, Figure 4). Thus, the replacement of one of the Cp* ligands from II with a five electron donor fragment $\left\{(\mathrm{Cp} * \mathrm{~W})_{2} \mathrm{~B}_{4} \mathrm{H}_{9}\right\}$, the 18-electron count for the bare $\mathrm{W}$ atom satisfied and hence this may be considered as an analogue to II. Both the NBO and MO analysis of 5 and II support these arguments (Figures 5a,d and S23-S24 ). Further, the HOMO shows large localization of electron density on the metal centers (Figure 5a and S23).

$$
\begin{array}{cccc}
{\left[(\mathrm{Cp} * \mathrm{~W})_{2} \mathrm{~B}_{4} \mathrm{H}_{10}\right]^{+}\left[\left(\mathrm{Cp}^{*} \mathrm{~W}\right)_{2} \mathrm{~B}_{5} \mathrm{H}_{9}\right]} & {\left[\left(\mathrm{Cp}{ }^{*} \mathrm{~W}\right)_{3} \mathrm{WB}_{9} \mathrm{H}_{18}\right]^{+} \mathrm{Cp} p^{*} \mathrm{H}} & \text { Eqn. } 1 \\
\mathrm{CVE}=44 & \mathrm{CVE}=46 & \mathrm{CVE}=84 \quad \mathrm{CVE}=6 &
\end{array}
$$

Cluster condensation or fusion by vertex, edge, or face sharing is quite familiar in polyhedral borane, metallaborane and carborane chemistry. ${ }^{38}$ Electron counting of these types of clusters can well be understood following Mingos's fusion formalism ${ }^{38 f}$ and Jemmis’s mno rule. ${ }^{24}$ Existence of cluster II led us to propose a plausible pathway for the formation of compound 5. From Eqn 1, it is reasonable to assume that, during the progress of the reaction, $\left[(\mathrm{Cp} * \mathrm{~W})_{2} \mathrm{~B}_{4} \mathrm{H}_{10}\right]$ and $\mathbf{I I}$ underwent a cluster condensation reaction to produce $\mathbf{5}$ with the elimination of a $\mathrm{Cp}^{*}$. As a result $\left\{(\mathrm{Cp} * \mathrm{~W})_{2} \mathrm{~B}_{4} \mathrm{H}_{9}\right\}$ acts as a ligand for the formation of $\left\{(\mathrm{Cp} * \mathrm{~W}) \mathrm{WB}_{5} \mathrm{H}_{9}\right]($ Chart 1$) .{ }^{39}$ 


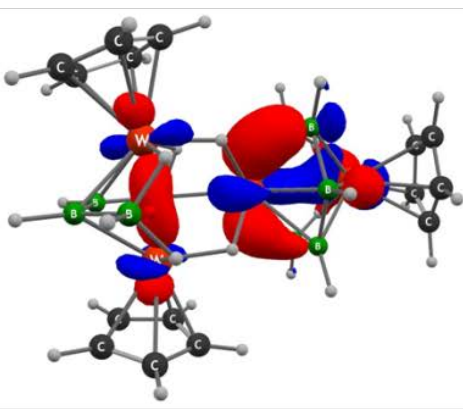

(a)

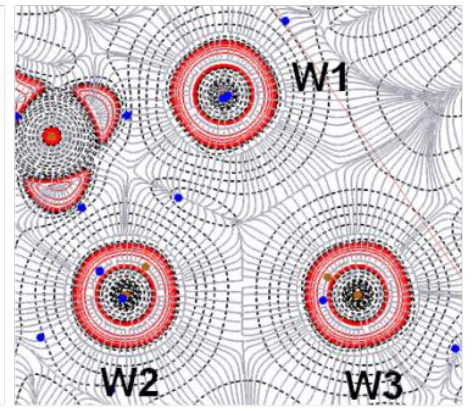

(b)

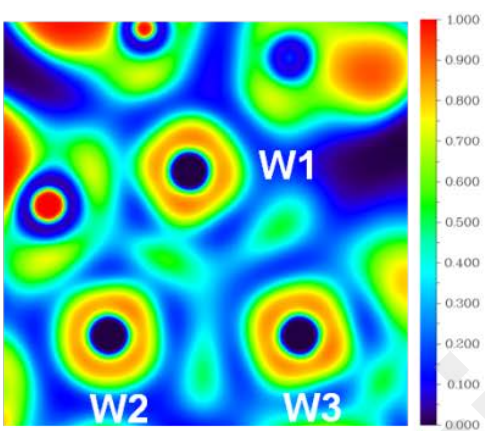

(c)

(d)
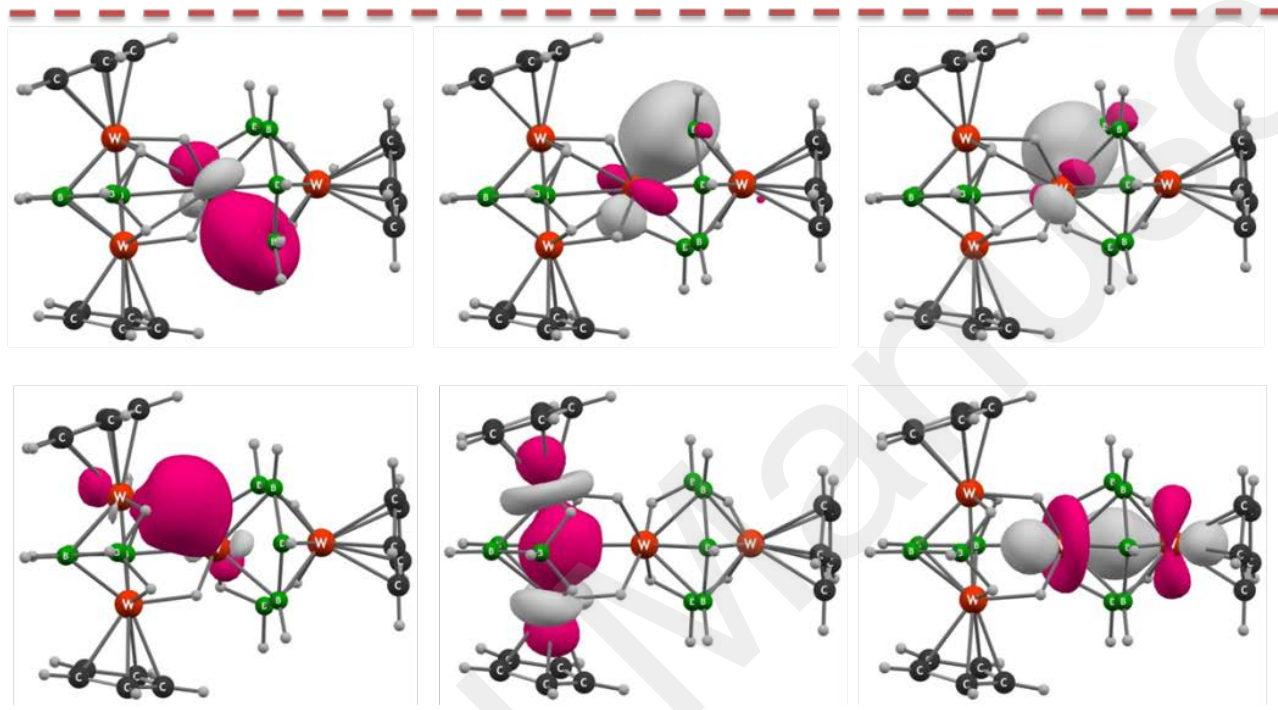

(e)

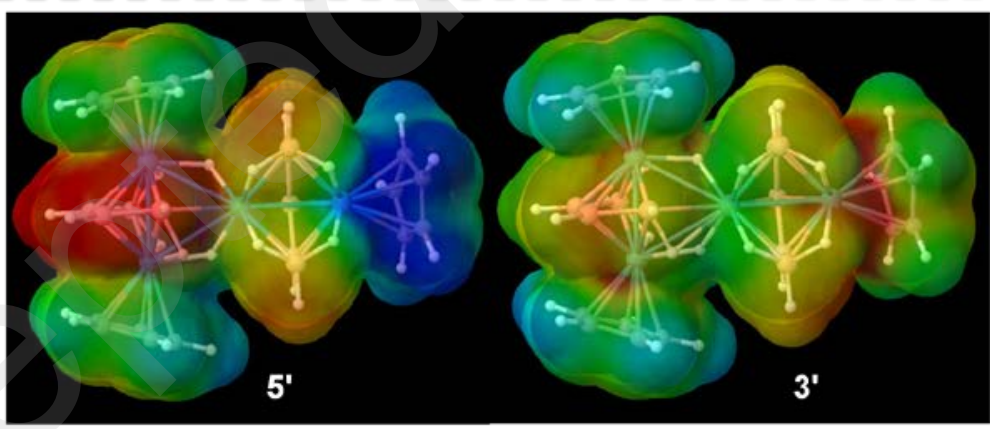

Depletion of charge 0.01

-0.01 Accumulation of charge

Figure 5. Bonding analyses of 5' [(a) shows the HOMO, (b) contour line diagram of the Laplacian of electron density in the plane of W1-W2-W3, (c) showing ELF plot in the plane of W1-W2-W3, (d) selected natural localized molecular orbital (NLMO) obtained from NBO analysis, (e) Electrostatic potential analysis]. 


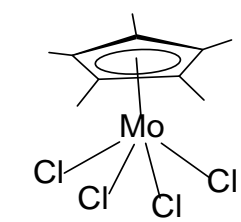

$$
\begin{array}{l|l}
\mathrm{LiBH}_{4}, & -72{ }^{\circ} \mathrm{C} \text { to } 15^{\circ} \mathrm{C} \\
\text { toluene } & 72 \mathrm{~h}
\end{array}
$$

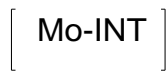

$$
\begin{gathered}
{\left[\mathrm{W}(\mathrm{CO}) 5^{\bullet} \mathrm{thf}\right]} \\
65^{\circ} \mathrm{C}, 24 \mathrm{~h}
\end{gathered}
$$
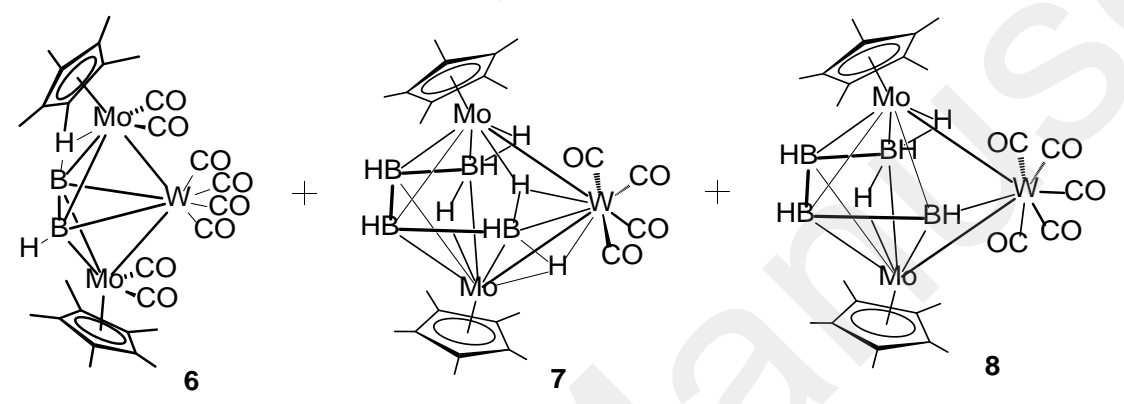

Scheme 3. Synthesis of diborene(2), (6) and heterometallaboranes (7 and 8). [Mo-INT] is an insitu generated intermediate, obtained from the reaction of $\left[\mathrm{Cp}^{*} \mathrm{MoCl}_{4}\right]$ and $\left[\mathrm{LiBH}_{4}\right]$ at $-72{ }^{\circ} \mathrm{C}$.

$\left[(\mathbf{C p} * \mathbf{M o})_{2} \mathbf{B}_{4} \mathbf{H}_{8} \mathrm{~W}(\mathrm{CO})_{4}\right], 7$ and $\left[(\mathrm{Cp} * \mathrm{Mo})_{2} \mathbf{B}_{4} \mathbf{H}_{6} \mathrm{~W}(\mathrm{CO})_{5}\right]$, 8: In order to replace $\{\mathrm{Cp} * \mathrm{Mo}$ $\left.(\mathrm{CO})_{2} \mathrm{H}\right\}$ unit in 4 with $\left\{\mathrm{W}(\mathrm{CO})_{5}\right\}$, we treated the intermediate, obtained from the reaction of $\left[\mathrm{Cp} * \mathrm{MoCl}_{4}\right]$ and $\left[\mathrm{LiBH}_{4}\right]$, with $\left\{\mathrm{W}(\mathrm{CO})_{5}\right.$.thf $\}$. The reaction yielded two trimetallic clusters $\left[(\mathrm{Cp} * \mathrm{Mo})_{2} \mathrm{~B}_{4} \mathrm{H}_{8}-\mathrm{W}(\mathrm{CO})_{4}\right], 7$ and $\left[(\mathrm{Cp} * \mathrm{Mo})_{2} \mathrm{~B}_{4} \mathrm{H}_{6} \mathrm{~W}(\mathrm{CO})_{5}\right], 8$ along with the formation of diborene(2) complex, $\quad\left[\left\{\mathrm{Cp} * \mathrm{Mo}(\mathrm{CO})_{2}\right\}_{2} \mathrm{~B}_{2} \mathrm{H}_{2} \quad \mathrm{~W}(\mathrm{CO})_{4} \quad\right.$ (6), reported recently in a communication. ${ }^{18}$ Since the landmark report of N-heterocyclic carbene (NHCs) stabilized diborene compounds by Robinson, the chemistry of unsaturated boron-boron species has extended significantly and in this respect, 6 is an exceptional entry to this diborene(2) species. ${ }^{40,41}$ Compounds $\mathbf{7}$ and $\mathbf{8}$ were isolated as brown and green solids in moderate yields. 
Room temperature ${ }^{11} \mathrm{~B}\left\{{ }^{1} \mathrm{H}\right\}$ NMR of compounds 7 and 8 appeared between $\delta=27$ and $103 \mathrm{ppm}$ (from high frequency to low frequency), with signals of $\mathbf{8}$ being relatively downfield shifted. The IR spectra of both $\mathbf{7}$ and $\mathbf{8}$ showed the stretching frequencies corresponding to the CO ligands and $\mathrm{BH}_{\mathrm{t}}$. The ${ }^{1} \mathrm{H}$ NMR spectra of $\mathbf{7}$ and $\mathbf{8}$ reveal the presence of one equivalent of $\mathrm{Cp}^{*}$ proton. Further, the mass spectrometric data suggest a close association between compounds $\mathbf{7}$ and $\mathbf{8}$.
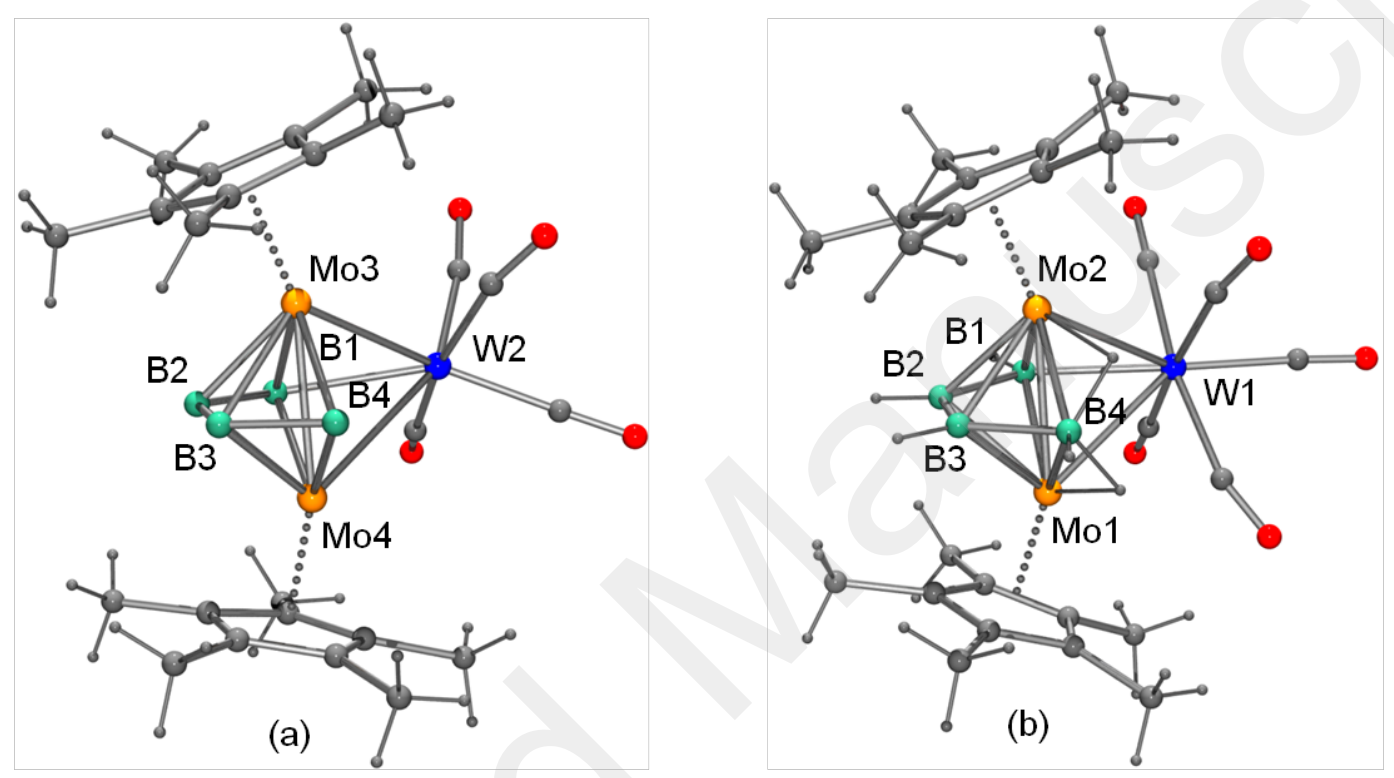

Figure 6. Molecular structure of (a) 7 and (b) 8. Bridging hydride ligands and the hydrogen atoms attached to the boron atoms of $\mathbf{7}$ could not be located. Selected bond lengths ( $\AA$ ) and bond angles $\left({ }^{\circ}\right)$. 7: Mo3-B2 2.1821(15), Mo3-B3 2.2380(16), Mo3-B4 2.2671(16), Mo3-B1 2.2841(16), Mo3-Mo4 2.8275(18), Mo3-W2 2.9908(15), W2-B4 2.3955(7), B1-B2 1.7399(3), B2-B3 1.7185(6), B3-B4 1.7003(7). Mo4-W2-Mo3 55.95(4), Mo3-B1-Mo4 75.87(5), Mo3-B4Mo4 75.73(5), 8: B1-B2 1.706(5), B1-Mo1 2.283(3), B1-W1 2.315(3), B2-B3 1.739(5), B2-Mo1 2.175(3), B3-B4 1.744(5), B3-Mo2 2.180(4), B4-Mo2 2.309(3), Mo1-W1 2.9801(3), Mo1-Mo2 2.8308(3), Mo2-B1-Mo1 77.17(10), B1-W1-Mo1 49.13(8), Mo1-W1-Mo2 56.588(7). 
Single crystals of $\mathbf{7}$ and $\mathbf{8}$ suitable for $\mathrm{X}$-ray diffraction were grown from hexane at $-10{ }^{\circ} \mathrm{C}$. The solid-state X-ray structures of $\mathbf{7}$ and $\mathbf{8}$, shown in Figures 6 (a) and 7(b) respectively, are consistent with the spectroscopic data. The core geometries are analogous to $\left[(\mathrm{Cp} * \mathrm{Cr})_{2} \mathrm{~B}_{4} \mathrm{H}_{8} \mathrm{Fe}(\mathrm{CO})_{3}\right]$ and $\left[(\mathrm{Cp} * \mathrm{Cr})_{2} \mathrm{Co}-(\mathrm{CO})_{3} \mathrm{~B}_{4} \mathrm{H}_{7}\right] .{ }^{42}$ Note that, the hydrogen atoms attached to boron could not be located by solid state X-ray diffraction study of $7^{43}$, however their positions were fixed based on ${ }^{1} \mathrm{H}$ NMR as shown in Scheme 3. As $\left\{\mathrm{W}(\mathrm{CO})_{4}\right\}$ and $\left\{\mathrm{W}(\mathrm{CO})_{5}\right\}$ are isolobal to $\left(\mathrm{BH}_{3}\right)$ and $(\mathrm{BH})$, compounds 7 and $\mathbf{8}$ are formally related to 46 cve (cluster valance electron) cluster $\mathbf{I}$. Thus, the core geometries of $\mathbf{7}$ and $\mathbf{8}$ can be viewed as a 6 sep oblato-nido hexagonal bipyramid or $\left\{\mathrm{Mo}_{2} \mathrm{~B}_{3} \mathrm{H}_{3}\right\}$ trigonal-bipyramidal core face capped by $\left(\mathrm{BH}_{3}\right)$ and $\left\{\mathrm{W}(\mathrm{CO})_{4}\right\}$ or $\left\{\mathrm{W}(\mathrm{CO})_{5}\right\}$ fragments. The Mo-Mo bond distances in 7, 8 and $\mathbf{I}$ are comparable (7: 2.8275(18), 8: 2.8308(3), [(Cp'Mo $\left.{ }_{2} \mathrm{~B}_{5} \mathrm{H}_{5}(\mu-\mathrm{H})_{4}\right]: 2.80 \AA$; Table 2), however they are shorter than those observed in $\left[\mathrm{CpMo}(\mathrm{CO})_{3}\right]_{2}(3.22 \AA)$ and $\left[\mathrm{Mo}_{2}(\mathrm{CO})_{10}\right]^{2-}(3.123 \AA){ }^{44}$

The HOMO and HOMO-1 of 8' (Figures 7b and c) shows electron localization over the metal centres. The HOMO, in particular, shows that the $\left\{\mathrm{W}(\mathrm{CO})_{5}\right\}$ fragment interacts through its half occupied $\pi$-symmetry orbital. The empty $\sigma$ orbital of the $\left\{\mathrm{W}(\mathrm{CO})_{5}\right\}$ fragment interacts with a low lying filled $\mathrm{Cp}^{*}$ Mo orbital leading to donor-acceptor interactions (Figures S26-S27). This was further supported by the electron density distribution analysis where the Laplacian plot showed more electron density along the Mo1-Mo2 than W1-Mo1/Mo2 (Figure 7f). As a result, the W centre attains the 18-electron rule. In addition, the MO analyses (HOMO and HOMO-1, Figures 7b and c, respectively) demonstrate week interactions between the Mo based d orbitals and $\pi^{*}$ of the CO ligands that established the week nature of Mo-CO interactions and more like terminal to W1 centre. This observation was also supported by the WBI values and the molecular graphs (Figures $7 \mathrm{~d}-\mathrm{e})$. On the other hand, the $\left[\mathrm{W}(\mathrm{CO})_{4}\right]$ moiety in 7 attached to $\left[(\mathrm{Cp} * \mathrm{Mo})_{2} \mathrm{~B}_{4} \mathrm{H}_{8}\right]$ 
through two face-bridging hydrogen and a pair of Mo-W interactions (Figure S25). An interesting statement that can be concluded from the NBO charge analysis of $\mathbf{8}$ ' is the diverse oxidation states of the metal centres. The comparatively reduced oxidation state of W1 (natural charge -1.57, whereas that of Mo centres are -0.87 and -0.84 ) indicates the flow of electron density predominantly towards W1 centre. This further supports the accepter behaviour of $\left[\mathrm{W}(\mathrm{CO})_{5}\right]$ moiety.

Table 2. Selected structural parameters of $\mathbf{7}$ and $\mathbf{8}$ and other related compounds.

\begin{tabular}{lllll}
\hline Compounds & sep & $d(\mathrm{M}-\mathrm{M})(\AA)$ & $d(\mathrm{M}-\mathrm{B})(\AA)^{a}$ & $d(\mathrm{~B}-\mathrm{B})(\AA)^{a}$ \\
\hline$\left[(\mathrm{Cp} * \mathrm{Cr})_{2} \mathrm{~B}_{4} \mathrm{H}_{8} \mathrm{Fe}(\mathrm{CO})_{3}\right]$ & 6 & $2.71^{\mathrm{a}}$ & 2.15 & 1.72 \\
{$\left[(\mathrm{Cp} * \mathrm{Cr})_{2} \mathrm{Co}(\mathrm{CO})_{3} \mathrm{~B}_{4} \mathrm{H}_{7}\right]$} & 6 & $2.69^{\mathrm{b}}$ & 2.13 & 1.69 \\
{$\left[(\mathrm{Cp} \mathrm{Mo})_{2} \mathrm{~B}_{5} \mathrm{H}_{5}(\mu-\mathrm{H})_{4}\right]$} & 6 & 2.81 & 2.26 & 1.73 \\
{$\left[(\mathrm{Cp} * \mathrm{~W})_{2} \mathrm{~B}_{5} \mathrm{H}_{5}(\mu-\mathrm{H})_{4}\right]$} & 6 & 2.82 & 2.26 & 1.71 \\
{$\left[(\mathrm{Cp} * \mathrm{Mo})_{2} \mathrm{~B}_{5} \mathrm{H}_{9} \mathrm{Fe}(\mathrm{CO})_{3}\right]$} & 7 & $2.94^{\mathrm{c}}$ & 1.75 & 1.76 \\
{$\left[(\mathrm{Cp} * \mathrm{~W})_{2} \mathrm{~B}_{5} \mathrm{H}_{9} \mathrm{Fe}(\mathrm{CO})_{3}\right]$} & 7 & $2.93^{\mathrm{d}}$ & 1.79 & 1.77 \\
7 & 6 & 2.83 & 2.24 & 1.72 \\
$\mathbf{8}$ & 6 & 2.83 & 2.24 & 1.73 \\
${ }^{a}$ average distance, $\mathrm{Cp}{ }^{\prime}=\left(\eta^{5}-\mathrm{MeC}_{5} \mathrm{H}_{4}\right)$ & & &
\end{tabular}




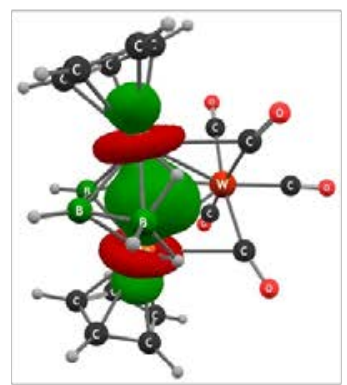

(a)

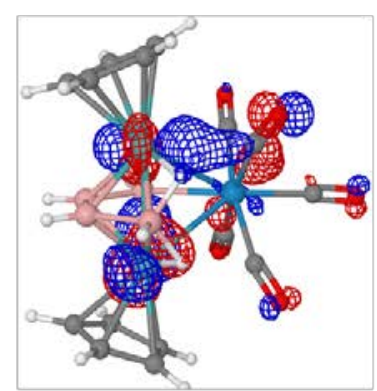

(b)

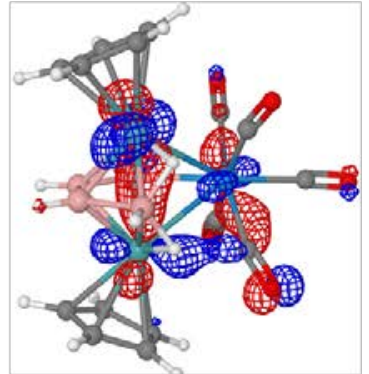

(c)

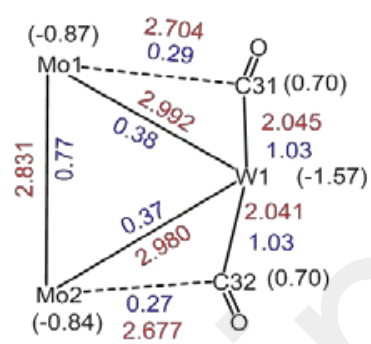

(d)

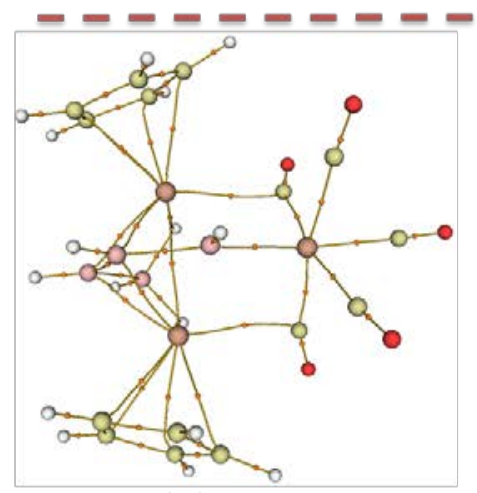

(e)

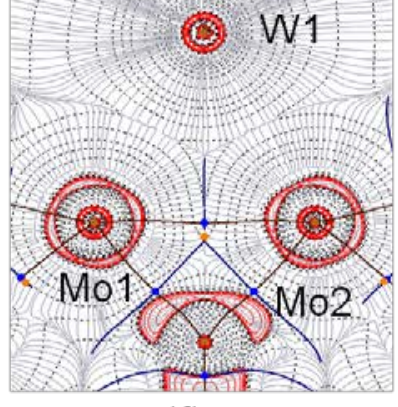

(f)

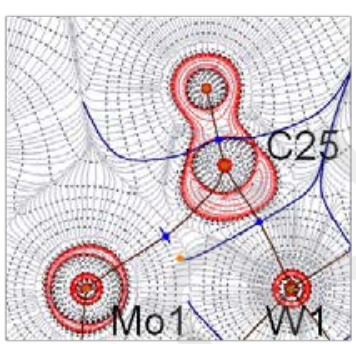

(g)

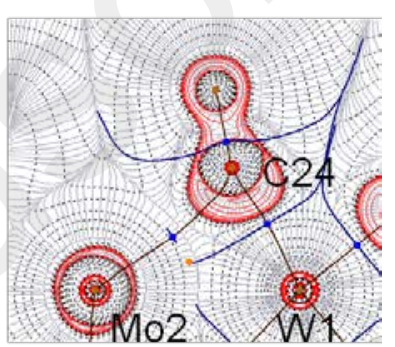

(h)

Figure 7. Mo-Mo bonding in 8' (Cp analogue of 8). (a) natural localized molecular orbital (NLMO) obtained from NBO analysis, (b) HOMO, (c) HOMO-1, (d) The $\mathrm{Mo}_{3}$-core (WBIs are shown in blue, bond distances in red and natural charges in parenthesis), (e) molecular graphs for the model 8', contour line diagrams of the Laplacian of electron density in $\mathrm{Mo}_{3}$ plane and (f) MoC-Mo planes (g-h) [solid red lines indicate areas of charge concentration $\left(\nabla^{2} \rho(r)<0\right)$, while dashed black lines show areas of charge depletion $\left.\left(\nabla^{2} \rho(r)>0\right)\right]$.

\section{CONCLUSION}

In summary, we have described the synthesis of molybdenum diborane(4) complex, $\left[\left\{\mathrm{Cp} * \mathrm{Mo}(\mathrm{CO})_{2}\right\}_{2}\left\{\mu-\eta^{2}: \eta^{2}-\mathrm{B}_{2} \mathrm{H}_{4}\right\}\right]$ (2) that not only shows the presence of unique $\mathrm{B}_{2} \mathrm{H}_{4}$ of $C_{s}$ type, it also mimics Cotton's dimolybdenum-acetylene complex, $\left[\left\{\mathrm{CpMo}(\mathrm{CO})_{2}\right\}_{2} \mathrm{C}_{2} \mathrm{H}_{2}\right]$. Our pursuit of growing the library of this type of complexes led us to isolate homoleptic molybdaboranes, $\left[\left(\mathrm{Cp}^{*} \mathrm{Mo}\right)_{3}(\mu-\mathrm{H})_{2}\left(\mu_{3}-\mathrm{H}\right)(\mu-\mathrm{CO})_{2} \mathrm{~B}_{4} \mathrm{H}_{4}\right]$ (4) and a vertex-fused cluster, 
$\left[(\mathrm{Cp} * \mathrm{~W})_{3} \mathrm{WB}_{9} \mathrm{H}_{18}\right]$ (5). Further, we have described the synthesis of two mixed metallaboranes, $\left[(\mathrm{Cp} * \mathrm{Mo})_{2} \mathrm{~B}_{4} \mathrm{H}_{8} \mathrm{~W}(\mathrm{CO})_{4}\right](7)$ and $\left[(\mathrm{Cp} * \mathrm{Mo})_{2} \mathrm{~B}_{4} \mathrm{H}_{6} \mathrm{~W}(\mathrm{CO})_{5}\right]$ (8) along with diborene(2) complex, $\left[\left\{\mathrm{Cp} * \mathrm{Mo}(\mathrm{CO})_{2}\right\}_{2} \mathrm{~B}_{2} \mathrm{H}_{2} \mathrm{~W}(\mathrm{CO})_{4}\right]$ (6). Electron counting as well as molecular orbital analyses suggest that metallaboranes $\mathbf{7}$ and $\mathbf{8}$ are the analogues of parent $\left(\left[(\mathrm{Cp} * \mathrm{Mo})_{2} \mathrm{~B}_{5} \mathrm{H}_{9}\right]\right)$ cluster. These results exemplify the presence of multimetallic molecular clusters with exciting geometry and bonding.

\section{EXPERIMENTAL SECTION}

General Procedures and Instrumentation. All the manipulations were conducted under an atmosphere of dry argon or in vacuo using standard Schlenk line or glove box techniques. Solvents (hexane, toluene, thf) were purified by distillation from appropriate drying agents(sodium/benzophenone) under dry argon prior to use. $\mathrm{CDCl}_{3}$ and $\mathrm{C}_{6} \mathrm{D}_{6}$ were degassed by three freeze-pump-thaw cycles and stored over molecular sieves. Compounds $\left[\mathrm{Cp}^{*} \mathrm{MCl}_{4}\right](\mathrm{M}=\mathrm{Mo}$

and $\mathrm{W}),\left[\mathrm{M}^{\prime}(\mathrm{CO})_{5} \cdot \mathrm{thf}\right],\left(\mathrm{M}^{\prime}=\mathrm{Cr}, \mathrm{Mo}\right.$ and $\left.\mathrm{W}\right)$ were prepared according to literature method, ${ }^{45}$ while other chemicals such as, $\left.\left[\mathrm{LiBH}_{4} \text {.thf] } 2.0 \mathrm{M} \text { in THF, } \mathrm{Cp} * \mathrm{H} \text {, n-BuLi, }\left[\mathrm{Cr}(\mathrm{CO})_{6}\right] \text {, [Mo(CO) }\right)_{6}\right]$ and $\left[\mathrm{W}(\mathrm{CO})_{6}\right]$ were obtained commercially (Aldrich) and used as received. MeI was purchased from Aldrich and freshly distilled prior to use. The external reference for the ${ }^{11} \mathrm{~B}$ NMR, $\left[\mathrm{Bu}_{4} \mathrm{~N}\left(\mathrm{~B}_{3} \mathrm{H}_{8}\right)\right]$ was synthesized with the literature method. ${ }^{46}$ Preparative thin layer chromatography was performed with Merck 105554 TLC silica gel $60 \mathrm{~F}_{254}$, layer thickness 250 $\mu \mathrm{m}$ on aluminium sheets $(20 \times 20 \mathrm{~cm})$. NMR spectra were recorded on 400 and $500 \mathrm{MHz}$ Bruker FT-NMR spectrometers. The residual solvent protons were used as reference $\left(\delta, \mathrm{ppm}, d_{6^{-}}\right.$ benzene, 7.16, $\left.\mathrm{CDCl}_{3}, 7.26\right)$, while a sealed tube containing $\left[\mathrm{Bu}_{4} \mathrm{~N}\left(\mathrm{~B}_{3} \mathrm{H}_{8}\right)\right]$ in $d_{6}$-benzene $\left(\delta_{\mathrm{B}}\right.$, ppm, -30.07) was used as an external reference for the ${ }^{11} \mathrm{~B}$ NMR. The infrared spectra were recorded on a Nicolet iS10 spectrometer. Electrospray mass (ESI-MS) spectra were recorded on 
a Qtof Micro YA263. The photo-reactions described in this report were conducted in a Luzchem LZC-4 V photo reactor, with irradiation at $254-350 \mathrm{~nm}$. MALDI-TOF mass spectra were recorded on a Bruker Ultraflextreme by using 2,5-dihydroxybenzoic acid as a matrix and a ground steel target plate and $\mathrm{CH}$ analyses were obtained on Perkin Elmer Instruments series II model 2400 .

Synthesis of 4: A solution of $1(0.140 \mathrm{~g}, 0.25 \mathrm{mmol})$ in toluene was treated with carbon monoxide over a period of 15 mins and the reaction mixture was stirred for $12 \mathrm{~h}$ at ambient temperature. The solvent was evaporated in vacuo and the crude was extracted with hexane: $\mathrm{CH}_{2} \mathrm{Cl}_{2}$ (80:20) solvent mixture and filtered through a frit using celite. After removal of solvent from the filtrate, the residue was subjected to chromatographic work-up using silica gel TLC plates. Elution with hexane: $\mathrm{CH}_{2} \mathrm{Cl}_{2}$ (75:25) solvent mixture afforded yellow 2 (0.052 g, $\left.32 \%\right){ }^{18}$ brown 3 (0.035 g, $15.4 \%)$ and brown 4 (0.020 g, 10\%).

4: HRMS (ESI $\left.{ }^{+}\right): m / z$ calculated for $\left[\mathrm{C}_{32} \mathrm{H}_{52} \mathrm{~B}_{4} \mathrm{Mo}_{3} \mathrm{O}_{2}+\mathrm{H}\right]^{+}$: 807.1579; found 807.1588; ${ }^{11} \mathrm{~B}\left\{{ }^{1} \mathrm{H}\right\}$ NMR $\left(22^{\circ} \mathrm{C}, 128 \mathrm{MHz}, \mathrm{CDCl}_{3}\right): \delta=23.5$ (br, 1B), 46.3 (br, 1B), 83.2 (br, 1B), 88.8 (br, 1B), ${ }^{1} \mathrm{H}$ NMR $\left(22{ }^{\circ} \mathrm{C}, 500 \mathrm{MHz}, \mathrm{CDCl}_{3}\right): \delta=4.82$ (br, 4H, B $\left.\underline{H}_{\mathrm{t}}\right), 1.95$ (s, 15H, 1Cp*), 1.91 (s, 30H, 2Cp*), -8.85, -9.35, -13.17 (br, 3H, Mo- $\underline{H}-\mathrm{B}) ;{ }^{13} \mathrm{C}\left\{{ }^{1} \mathrm{H}\right\}$ NMR $\left(22{ }^{\circ} \mathrm{C}, 125 \mathrm{MHz}, \mathrm{CDCl}_{3}\right): \delta=$ 187.2, 183. 9 (CO), 102.4, $100.2\left(\underline{C}_{5} \mathrm{Me}_{5}\right), 13.0,10.8\left(\mathrm{C}_{5} \underline{\underline{M e}} 5\right)$; IR (hexane) $v / \mathrm{cm}^{-1}$ : 2420(BH $\left.\mathrm{BH}_{\mathrm{t}}\right), 1787(\mathrm{CO}), 1729(\mathrm{CO})$.

Synthesis of 5: In a flame-dried Schlenk tube [Cp*WCl $]$, $(0.1 \mathrm{~g}, 0.22 \mathrm{mmol})$ in $15 \mathrm{~mL}$ of toluene was treated with 5 -fold excess of $\left[\mathrm{LiBH}_{4} . \mathrm{THF}\right](0.55 \mathrm{~mL}, 1.1 \mathrm{mmol})$ at $-40^{\circ} \mathrm{C}$ and allowed to stir at allowed to stir at $10^{\circ} \mathrm{C}$ for 48 hour.In the reaction mixture $\mathrm{CO}(\mathrm{g})$ passed for 12 hour at room temperature. After removal of toluene, the residue was extracted into hexane and 
filtered through a frit using Celite. After removal of solvent from the filtrate, the residue was subjected to chromatographic workup using silica gel TLC plates. Elution with a hexane/ $\mathrm{CH}_{2} \mathrm{Cl}_{2}$ (75:15 v/v) mixture yielded brown 5 (0.030 g, 10.9\%) along with known [(Cp*W $\left.)_{2} \mathrm{~B}_{5} \mathrm{H}_{9}\right](0.048$ g, 31\%).

5: HRMS $\left(\right.$ ESI $\left.^{+}\right): m / z$ calculated for $\left[\mathrm{C}_{30} \mathrm{H}_{63} \mathrm{~B}_{9} \mathrm{~W}_{4}+\mathrm{H}\right]^{+}$: 1259.3883; found 1259.3915;. ${ }^{11} \mathrm{~B}\left\{{ }^{1} \mathrm{H}\right\}$ NMR (22 ${ }^{\circ} \mathrm{C}, 128 \mathrm{MHz}, \mathrm{CDCl}_{3}$ ): $\delta=55.3$ (br, 1B), 51.0 (br, 1B), 47.8 (br, 1B), 45.8 (br, 1B), 44.6 (br, 1B), 40.7 (br, 1B), 27.6 (br, 1B), 24.5 (br, 1B), 21.9 (br, 1B). ${ }^{1} \mathrm{H}$ NMR $\left(22{ }^{\circ} \mathrm{C}, 500\right.$ MHz, $\left.\mathrm{CDCl}_{3}\right): \delta=6.19\left(\mathrm{br}, \mathrm{BH}_{\mathrm{t}}\right.$ ), $2.22(\mathrm{~s}, 15 \mathrm{H}, 1 \mathrm{Cp} *), 2.20$ (s, 15H, 1Cp*) 2.19 (s, 15H, 1Cp*), 1.79 (br, 1H, B-H-B), -3.61 (br, 1H, B-H-B), -7.58 (br, 1H, W-H-B), -8.56 (br, 2H, W-H-B), 9.58 (br, 1H, W-H-B), -10.64 (br, 1H, W-H-B), -13.08 (br, $1 \mathrm{H}, \mathrm{W}-\mathrm{H}-\mathrm{B}) .{ }^{13} \mathrm{C}\left\{{ }^{1} \mathrm{H}\right\}$ NMR (22 $\left.{ }^{\circ} \mathrm{C}, 100 \mathrm{MHz}, \mathrm{CDCl}_{3}\right): \delta=108.8\left(\underline{\mathrm{C}}_{5} \mathrm{Me}_{5}\right), 107.2\left(\underline{C}_{5} \mathrm{Me}_{5}\right), 12.6\left(\mathrm{C}_{5} \underline{M e}_{5}\right), 11.6\left(\mathrm{C}_{5} \underline{\mathrm{Me}}_{5}\right) . \mathrm{IR}$ (hexane) $v / \mathrm{cm}^{-}: 2473\left(\mathrm{BH}_{\mathrm{t}}\right)$.

Synthesis of 7 and 8: In a flame-dried Schlenk tube [Cp* $\left.\mathrm{MoCl}_{4}\right],(0.1 \mathrm{~g}, 0.27 \mathrm{mmol})$ in $10 \mathrm{~mL}$ of toluene was treated with 5-fold excess of $\left[\mathrm{LiBH}_{4} . \mathrm{THF}\right](0.7 \mathrm{~mL}, 1.4 \mathrm{mmol})$ at $-40^{\circ} \mathrm{C}$ and allowed to stir at room temperature for one hour. After removal of toluene, the residue was extracted into hexane and filtered through a frit using Celite. The brownish-green hexane extract was dried in vacuo, and taken in $10 \mathrm{~mL}$ of THF and heated at $65^{\circ} \mathrm{C}$ with [W(CO) 5 .THF] for 24 hours. The solvent was evaporated in vacuo and residue was extracted into hexane and passed through celite. After removal of solvent from the filtrate, the residue was subjected to chromatographic workup using silica gel TLC plates. Elution with a hexane/ $\mathrm{CH}_{2} \mathrm{Cl}_{2}(80: 10 \mathrm{v} / \mathrm{v})$ mixture yielded dark brown 7 (0.025 g, 11.4\%) and green 8 (0.025 g, 11\%). 
7: HRMS $\left(\mathrm{ESI}^{+}\right): \mathrm{m} / \mathrm{z}$ calculated for $\left[\mathrm{C}_{24} \mathrm{H}_{38} \mathrm{~B}_{4} \mathrm{O}_{4} \mathrm{Mo}_{2} \mathrm{~W}_{1}+\mathrm{Na}\right]^{+}$: 837.0657; found 837.0647; ${ }^{11} \mathrm{~B}\left\{{ }^{1} \mathrm{H}\right\}$ NMR $\left(22{ }^{\circ} \mathrm{C}, 128 \mathrm{MHz}, \mathrm{CDCl}_{3}\right): \delta=27.9$ (br, 1B), 41.9 (br, 1B), 81.2 (br, 2B); ${ }^{1} \mathrm{H}$ NMR $\left(22{ }^{\circ} \mathrm{C}, 400 \mathrm{MHz}, \mathrm{CDCl}_{3}\right): \delta=4.46$, (br, $\left.\mathrm{BH}_{\mathrm{t}}\right), 2.03$ (s, 30H, 2Cp*), -6.90 (br, 2H, Mo-H-B), 10.17 (br, $1 \mathrm{H}, \mathrm{W}-\mathrm{H}-\mathrm{B}),-13.32$ (br, $1 \mathrm{H}, \mathrm{Mo}-\mathrm{H}-\mathrm{W}) ;{ }^{13} \mathrm{C}\left\{{ }^{1} \mathrm{H}\right\}$ NMR $\left(22{ }^{\circ} \mathrm{C}, 100 \mathrm{MHz}, \mathrm{CDCl}_{3}\right): \delta$ =195.4, 189.4, 181.7 (CO), $98.9\left(\underline{C}_{5} \mathrm{Me}_{5}\right), 10.9\left(\mathrm{C}_{5} \underline{M_{5}}\right)$; IR (hexane) $v / \mathrm{cm}^{-1}: 2474\left(\mathrm{BH}_{\mathrm{t}}\right)$, 2008(CO), 1937(CO), 1878 (CO)

8: HRMS $\left(\mathrm{ESI}^{+}\right)$: $\mathrm{m} / \mathrm{z}$ calculated for $\left[\mathrm{C}_{25} \mathrm{H}_{36} \mathrm{~B}_{4} \mathrm{O}_{5} \mathrm{Mo}_{2} \mathrm{~W}_{1}+\mathrm{H}\right]^{+}$: 841.0630; found 841.0623; ${ }^{11} \mathrm{~B}\left\{{ }^{1} \mathrm{H}\right\}$ NMR $\left(22^{\circ} \mathrm{C}, 128 \mathrm{MHz}, \mathrm{CDCl}_{3}\right): \delta=103.0(\mathrm{br}, 2 \mathrm{~B}), 77.9$ (br, 1B), 77.0 (br, 1B); ${ }^{1} \mathrm{H}$ NMR $\left(22{ }^{\circ} \mathrm{C}, 400 \mathrm{MHz}, \mathrm{CDCl}_{3}\right): \delta=5.87$, (br, $\left.\mathrm{BH}_{\mathrm{t}}\right), 1.93$ (s, 30H, 2Cp*), -6.55 (br, 1H, Mo-H-B), 7.35 (br, 1H, Mo-H-B); ${ }^{13} \mathrm{C}\left\{{ }^{1} \mathrm{H}\right\}$ NMR $\left(22{ }^{\circ} \mathrm{C}, 100 \mathrm{MHz},\left[\mathrm{D}_{6}\right.\right.$ ]-benzene): $\delta=198.6,192.9$ (CO), $108.5\left(C_{5} \mathrm{Me}_{5}\right), 12.9$ ( $\left.\mathrm{C}_{5} \mathrm{Me}_{5}\right)$; IR (hexane) $v / \mathrm{cm}^{-1}: 2498\left(\mathrm{BH}_{\mathrm{t}}\right), 2043$ (CO), 2008(CO), 1969 (CO), 1890(CO).

Computational details. Geometry optimizations and electronic structure calculations were

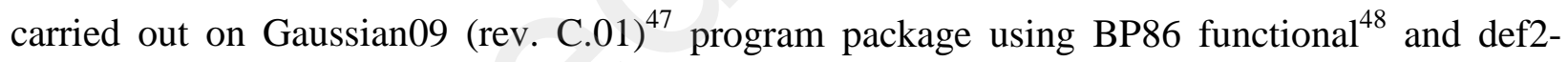
$\mathrm{TZV}^{49}$ basis set from EMSL Basis Set Exchange Library. The 28 core electrons of molybdenum and tungsten were replaced by the quasi-relativistic effective core potential def2-ECP. ${ }^{50}$ Vibrational analyses were carried out for all structures, and the absence of any imaginary frequency confirmed that all structures represent minima on the potential energy hypersurface. The NMR chemical shifts were calculated on the BP86/def2-TZVP optimized geometries using the hybrid Becke-Lee-Yang-Parr (B3LYP) functional and aforementioned basis set. ${ }^{51}$ The NMR calculation utilized gauge-including atomic orbitals (GIAOs) method. ${ }^{52}$ The ${ }^{11} \mathrm{~B}$ NMR chemical shifts were calculated relative to $\mathrm{B}_{2} \mathrm{H}_{6}$ (B3LYP B shielding constant $84.23 \mathrm{ppm}$ ) and converted to the usual $\left[\mathrm{BF}_{3} . \mathrm{OEt}_{2}\right]$ scale using the experimental $\delta\left({ }^{11} \mathrm{~B}\right)$ value of $\mathrm{B}_{2} \mathrm{H}_{6}, 16.6 \mathrm{ppm}$. 
Natural bonding analyses were performed with the natural bond orbital (NBO) partitioning scheme as implemented in the Gaussian 09 suite of programs. ${ }^{53}$ Wiberg bond indexes (WBI) were obtained on natural bond orbital analysis. ${ }^{54}$ In order to understand the nature of bonding of the synthesized molecules in greater detail, the topological properties of the resultant electron density, $\rho$, obtained from the wave functions of all the optimized structures were analyzed with the quantum theory of atoms in molecules (QTAIM). ${ }^{55}$ The QTAIM analysis were carried out utilizing Multiwfn V.3.3.8 package $^{56}$ whereas the wave functions were generated with Gaussian09 at the same level of theory as was used for geometry.

X-ray Structure Determination. Crystal data for 4, 5 and 8 were collected and integrated using Bruker Kappa apexII CCD single crystal diffractometer and for 7 with OXFORD Diffraction SUPER NOVA CCD Diffractometer, equipped with graphite monochromated Mo-K $\alpha$ ( $\lambda=$ $0.71073 \AA$ ) radiation. Data collection for $\mathbf{4}$ and $\mathbf{8}$ were carried out at $296 \mathrm{~K}$ and for $\mathbf{5}$ and $\mathbf{7}$ at $293 \mathrm{~K}$, using $\omega-\varphi$ scan modes. Multi-scan absorption correction has been employed for the data using SADABS ${ }^{57}$ program. The structures were solved by heavy atom methods using SHELXS97 or SIR92 ${ }^{58}$ and refined using SHELXL-2014. ${ }^{59}$ These data can be obtained free of charge from The Cambridge Crystallographic Data Centre via www.ccdc.cam.ac.uk/ data_request/cif

\section{ASSOCIATED CONTENT}

Supporting Information. The Supporting Information is available free of charge on the ACS Publications website.

Spectroscopic data for 4-5 and 7-8; optimized geometries and MO diagrams (PDF).

CCDC 1878369 (4), 1878370 (5) 1878367 (7) and 1878368 (8) contain the supplementary crystallographic data for this paper. These data can be obtained free of charge via 
www.ccdc.cam.ac.uk/data_request/cif, or by emailing data_request@ccdc.cam.ac.uk, or by contacting The Cambridge Crystallographic Data Centre, 12 Union Road, Cambridge CB2 1EZ, UK; fax: +44 1223336033

\section{AUTHOR INFORMATION}

Corresponding Author

*E-mail: sghosh@iitm.ac.in. Tel: +91-44-22574230. Fax: +91 44-22574202

ORCID $\odot 0000-0001-6089-8244$

Notes

The authors declare no competing financial interest.

\section{ACKNOWLEDGMENT}

The authors acknowledge the Council of Scientific \& Industrial Research (CSIR) (Project No. 01(2939)/18/emr-ii), New Delhi, India for financial support. R.B thanks IIT Madras for research fellowship.

\section{REFERENCES}

(1) (a) Stock, A. Hydrides of Boron and Silicon. Cornell University Press, Ithaca, New York, 1933. (b) Greenwood, N. N.; Earnshaw, A. Chemistry of the Elements (2nd ed.). ButterworthHeinemann, Ed. 1997.

(2) (a) Handbook of Boron Science: With Application in Organometallics, Catalysis, Materials and Medicines, Hosmane, N.S.; Eagling, R. Eds. World Scientific, 2018. (b) Boron and 
Gadolinium Neutron Capture Therapy for Cancer Treatment, Hosmane, N. S.; Maguire, J. A.; Zhu, Y.; Takagaki, M. World Scientific, 2012.

(3) Reed, C. A. Carborane acids. New "strong yet gentle" acids for organic and inorganic chemistry. Chem. Commun. 2005, 1669-1677.

(4) (a) Plešek, J. Potential applications of the boron cluster compounds. Chem. Rev. 1992, 92, 269-278. (b) Lu, X.; Shao, L.; Wang, X.; Chen, Q.; Liu, J.; Chu, W-K. Shallow Junction Formation By Small Cluster Implantation. Proc. Electrochem. Soc. 2001, 2001-9, 337-344. (c) Baše, T.; Bastl, Z.; Šlouf, M.; Klementová, M.; Šubrt, J.; Vetushka, A.; Ledinský, M.; Fejfar, A.; Macháček, J.; Carr, M. J.; Londesborough, M. G. S. Gold Micrometer Crystals Modified with Carboranethiol Derivatives. J. Phys. Chem. C 2008, 112, 14446-14455.

(5) (a) Barton, L.; Srivastava, S. K. in Comprehensive Organometallic Chemistry II, Vol. 1 Wilkinson, G.; Abel, E. W.; Stone, F. G. A. Eds. chap. 8.boranes and mimicking Pergamon, New York, 1995. (b) Fehlner, T. P. Borane Mimics of $C_{1}-M_{m}$ Organometallic Complexes. Angew. Chem. Int. Ed. 2005, 44, 2056-2058. (c) Mondal, B.; Borthakur, R.; Ghosh, S. Organometallic Chemistry and Catalysis of Transition Metal-Borane Compounds, Vol. 2, Ch. 7 in Handbook of Boron Science: With Application in Organometallics, Catalysis, Materials and Medicines, Hosmane, N. S.; Eagling, R. Eds. World Scientific, 2018.

(6) (a) Longuet-Higgins, H. C.; Bell, R. P. The structure of the boron hydrides. J. Chem. Soc. 1943, 250-255. (b) Laszlo, P. A. Diborane Story. Angew. Chem. Int. Ed. 2000, 39, 2071-2072.

(7) (a) Mohr, R. R.; Lipscomb, W. N. Structures and energies of diborane(4). Inorg. Chem. 1986, 25, 1053-1057. (b) Knight, L. B. Jr.; Kerr, K.; Miller, P. K.; Arrington, C. A. ESR 
Investigation of the HBBH(X3.SIGMA.) Radical in Neon and Argon Matrixes at $4 \mathrm{~K}$. Comparison with ab Initio SCF and CI Calculations. J. Phys. Chem. 1995, 99, 16842-16848.

(8) Neeve, E. C.; Geier, S. J.; Mkhalid, I. A. I.; Westcott, S. A.; Marder, T. B. Diboron(4) Compounds: From Structural Curiosity to Synthetic Workhorse. Chem. Rev. 2016, 116, 90919161.

(9) (a) Irvine, G. J.; Lesley, M. J. G.; Marder, T. B.; Norman, N. C.; Rice, C. R.; Robins, E. G.; Roper, W. R.; Whittell, G. R.; Wright, L. J. Transition Metal-Boryl Compounds: Synthesis, Reactivity, and Structure. Chem. Rev. 1998, 98, 2685-2722. (b) Bontemps, S.; Vendier, L.; Sabo-Etienne, S. Ruthenium-Catalyzed Reduction of Carbon Dioxide to Formaldehyde. J. Am. Chem. Soc. 2014, 136, 4419-4425.

(10) (a) Ishiyama, T.; Matsuda, N.; Miyaura, N.; Suzuki, A. Platinum(0)-catalyzed diboration of alkynes. J. Am. Chem. Soc. 1993, 115, 11018-11019. (b) Baker, R. T.; Nguyen, P.; Marder, T. B.; Westcott, S. A. Transition Metal Catalyzed Diboration of Vinylarenes. Angew. Chem. Int. Ed. 1995, 34, 1336-1338. (c) Mann, G.; John, K. D.; Baker, R. T. Platinum-Catalyzed Diboration Using a Commercially Available Catalyst: Diboration of Aldimines to $\alpha$-Aminoboronate Esters. Org. Lett. 2000, 2, 2105-2108. (d) Laitar, D. S.; Müller, P.; Sadighi, J. P. Efficient Homogeneous Catalysis in the Reduction of $\mathrm{CO}_{2}$ to CO. J. Am. Chem. Soc. 2005, 127, 17196-17197.

(11) Ishiyama, T.; Miyaura, N. Metal-catalyzed reactions of diborons for synthesis of organoboron compounds. Chem. Rec. 2004, 3, 271-280.

(12). Ritter, S. K. Boron chemistry branches out. Chem. Eng. News 2016, 94, 20-23. 
(13) (a) Irvine, G. J.; Lesley, M. J. G.; Marder, T. B.; Norman, N. C.; Rice, C. R.; Robins, E. G.; Roper, W. R.; Whittell, G. R.; Wright, L. J. Transition Metal-Boryl Compounds: Synthesis, Reactivity, and Structure. Chem. Rev. 1998, 98, 2685 - 2722. (b) Westcott, S. A.; Fernández, E. Singular Metal Activation of Diboron Compounds. Adv. Organomet. Chem. 2015, 63, 39-89.

(14) (a) Braunschweig, H.; Wagner, T. Synthesis and Structure of the First Transition Metal Borylene Complexes. Angew. Chem. Int. Ed. 1995, 34, 825-826. (b) Braunschweig, H.; Colling, M.; Hu, C.; Radacki, K. From Classical to Nonclassical Metal-Boron Bonds: Synthesis of a Novel Metallaborane. Angew. Chem. Int. Ed. 2002, 41, 1359-1361. (c) Braunschweig, H.; Burschka, C.; Burzler, M.; Metz, S.; Radacki, K. Molecular Structure and Cluster Formation of a tert-Butylborylene Complex. Angew. Chem. Int. Ed. 2006, 45, 4352-4355.

(15) (a) Kaesz, H. D.; Fellmann, W.; Wilkes, G. R.; Dahl, L. F. A New Type of ElectronDeficient Compound. A Polyborane Hydridomanganese Carbonyl, $\mathrm{HMn}_{3}(\mathrm{CO})_{10}\left(\mathrm{BH}_{3}\right)_{2}$. J. Am. Chem. Soc. 1965, 87, 2753 - 2755. (b) Arnold, N.; Braunschweig, H.; Dewhurst, R. D.; Ewing, W. C. Unprecedented Borane, Diborane(3), Diborene, and Borylene Ligands via Pt-Mediated Borane Dehydrogenation. J. Am. Chem. Soc. 2016, 138, 76-79. (c) Sharmila, D.; Mondal, B.; Ramalakshmi, R.; Kundu, S.; Varghese, B.; Ghosh, S. First-Row Transition-Metal-Diborane and -Borylene Complexes. Chem. Eur. J. 2015, 21, 5074-5083.

(16) (a) Hata, M.; Kawano, Y.; Shimoi, M. Synthesis and Structure of a Dichromatetraborane Derivative $\left[\left\{(\mathrm{OC})_{4} \mathrm{Cr}\right\}_{2}\left(\eta^{4}-\mathrm{H}, \mathrm{H}^{‘}, \mathrm{H}^{\prime}{ }^{\prime}, \mathrm{H}^{\text {‘ }}-\mathrm{BH}_{2} \mathrm{BH}_{2} \cdot \mathrm{PMe}_{2} \mathrm{CH}_{2} \mathrm{PMe}_{2}\right)\right]$. Inorg. Chem. 1998, 37, 4482-4483. (b) Braunschweig, H.; Damme, A.; Dewhurst, R. D.; Vargas, A. Bond-strengthening $\pi$ backdonation in a transition-metal $\pi$-diborene complex. Nat. Chem. 2013, 5, 115-121. (c) Wang, S. R.; Prieschl, D.; Mattock, J. D.; Arrowsmith, M.; Pranckevicius, C.; Stennett, T. E.; 
Dewhurst, R. D.; Vargas, A.; Braunschweig, H. Bottleable Neutral Analogues of $\left[\mathrm{B}_{2} \mathrm{H}_{5}\right]^{-}$as Versatile and Strongly Binding $\eta^{2}$ Donor Ligands. Angew. Chem., Int. Ed. 2018, 57, 6347-6351. (d) Rochette, É.; Bouchard, N.; Lavergne, J. L.; Matta, C. F.; Fontaine, F.-G. Spontaneous Reduction of a Hydroborane To Generate a B-B Single Bond by the Use of a Lewis Pair. Angew. Chem., Int. Ed. 2016, 55, 12722-12726.

(17) (a) Ting, C.; Messerle, L. Borohydride boron-hydrogen activation and dimerization by a doubly bonded, early-transition-metal organodimetallic complex. Ditantalladiborane syntheses as models for dehydrodimerization of methane to ethane. J. Am. Chem. Soc. 1989, 111, 3449-3450. (b) Brunner, H.; Gehart, G.; Meier, W.; Wachter, J.; Wrackmeyer, B.; Nuber, B.; Ziegler, M. L. Präparative, ${ }^{11} \mathrm{~B}-,{ }^{93} \mathrm{Nb}$-NMR-spektroskopische und strukturelle Untersuchungen an $\mathrm{Cp}_{2} \mathrm{NbBH}_{4^{-}}$ und $\left[\mathrm{CpNb}\left(\mathrm{B}_{2} \mathrm{H}_{6}\right)\right]_{2}-$ Komplexen. J. Organomet. Chem. 1992, 436, 313-324. (c) Bose, S. K.; Geetharani, K.; Ramkumar, V.; Mobin, S. M.; Ghosh, S. Fine Tuning of Metallaborane Geometries: Chemistry of Metallaboranes of Early Transition Metals Derived from Metal Halides and Monoborane Reagents. Chem. Eur. J. 2009, 15, 13483-13490. (d) Anju, R. S.; Roy, D. K.; Mondal, B.; Yuvaraj, K.; Arivazhagan, C.; Saha, K.; Varghese, B.; Ghosh, S. Reactivity of Diruthenium and Dirhodium Analogues of Pentaborane(9): Agostic versus Boratrane Complexes. Angew. Chem. Int. Ed., 2014, 53, 2873-2877.

(18) Mondal, B.; Bag, R.; Ghorai, S.; Bakthavachalam, K.; Jemmis, E. D.; Ghosh, S. Synthesis, Structure, Bonding, and Reactivity of Metal Complexes Comprising Diborane(4) and Diborene(2): $\left[\left\{\mathrm{Cp} * \mathrm{Mo}(\mathrm{CO})_{2}\right\}_{2}\left\{\mu-\eta^{2}: \eta^{2}-\mathrm{B}_{2} \mathrm{H}_{4}\right\}\right]$ and $\left[\left\{\mathrm{Cp} * \mathrm{M}(\mathrm{CO})_{2}\right\}_{2} \mathrm{~B}_{2} \mathrm{H}_{2} \mathrm{M}(\mathrm{CO})_{4}\right], \mathrm{M}=\mathrm{Mo}, \mathrm{W}$. Angew. Chem. Int. Ed. 2018, 57, 8079-8083. 
(19) (a) Grebenik, P. D.; Green, M. L. H.; Kelland, M. A.; Leach, J. B.; Mountford, P. Terminal substitution and cage incorporation of an $\eta$-cyclopentadienyl ring into borane cage structures; crystal structures of $\left[\mathrm{Mo}\left(\eta-\mathrm{C}_{5} \mathrm{H}_{5}\right)\left(\eta^{5}: \eta^{1}-\mathrm{C}_{5} \mathrm{H}_{4}\right) \mathrm{B}_{4} \mathrm{H}_{7}\right]$ and $\left[\mathrm{Mo}\left(\eta-\mathrm{C}_{5} \mathrm{H}_{5}\right)\left(\eta^{3}: \eta^{2}-\right.\right.$ $\left.\mathrm{C}_{3} \mathrm{H}_{3}\right) \mathrm{C}_{2} \mathrm{~B}_{9} \mathrm{H}_{9}$ ]. J. Chem. Soc. Chem. Commun. 1989, 1397-1399. (b) Saxena, A. K.; Hosmane, N. S. Recent advances in the chemistry of carborane metal complexes incorporating d- and fblock elements. Chem. Rev. 1993, 93, 1081-1124. (c) Fehlner, T. P. Systematic Metallaborane Chemistry. Organometallics 2000, 19, 2643-2651. (d) Kennedy, J. D. The Polyhedral Metallaboranes Part I. Metallaborane Clusters with Seven Vertices and Fewer, Ch. 6. in Progress in Inorganic Chemistry, Vol. 32, Lippard, S. J. Ed. 2007. (e) Kennedy, J. D. The Polyhedral Metallaboranes Part II. Metallaborane Clusters with Eight Vertices and More, Ch. 4, in Progress in Inorganic Chemistry, Vol. 34, Lippard, S. J. Ed. 2007.

(20) (a) De, A.; Zhang, Q.-F.; Mondal, B.; Cheung, L. F.; Kar, S.; Saha, K.; Varghese, B.; Wang, L.-S.; Ghosh, S. [(Cp $\left.\left.{ }_{2} \mathrm{M}\right)_{2} \mathrm{~B}_{9} \mathrm{H}_{11}\right]$ (M = Zr or Hf): early transition metal 'guarded' heptaborane with strong covalent and electrostatic bonding. Chem. Sci. 2018, 9, 1976-1981. (b) Bose, S. K.; Geetharani, K.; Varghese, B.; Mobin, S. M.; Ghosh, S. Metallaboranes of the Early Transition Metals: Direct Synthesis and Characterization of $\left[\left\{\left(\eta^{5}-C_{5} M e_{5}\right) T a\right\}_{2} B_{n} H_{m}\right](n=4$, $\mathrm{m}=10 ; \mathrm{n}=5, \mathrm{~m}=11),\left[\left\{\left(\eta^{5}-\mathrm{C}_{5} \mathrm{Me}_{5}\right) \mathrm{Ta}\right\}_{2} \mathrm{~B}_{5} \mathrm{H}_{10}\left(\mathrm{C}_{6} \mathrm{H}_{4} \mathrm{CH}_{3}\right)\right]$, and $\left[\left\{\left(\eta^{5}-\mathrm{C}_{5} \mathrm{Me}_{5}\right) \mathrm{TaCl}\right\}_{2} \mathrm{~B}_{5} \mathrm{H}_{11}\right]$. Chem. Eur. J. 2008, 14, 9058-9064; (c) Dhayal, R. S.; Chakrahari, K. K. V.; Varghese, B.; Mobin, S. M.; Ghosh, S. Chemistry of Molybdaboranes: Synthesis, Structures, and Characterization of a New Class of Open-Cage Dimolybdaheteroborane Clusters. Inorg. Chem. 2010, 49, 7741-7747. (d) Bose, S. K.; Geetharani, K.; Sahoo, S.; Reddy, K. H. K.; Varghese, B.; Jemmis, E. D.; Ghosh, S. Synthesis, Characterization, and Electronic Structure of New Type of Heterometallic Boride Clusters. Inorg. Chem. 2011, 50, 9414-9422. 
(21) (a) Boron hydride chemistry. Muetterties, E. L. Ed. Academic Press, New York, 1975.

(b) Fehlner, T. P.; Halet, J.-F.; Saillard, J.-Y.; Molecular Clusters. A Bridge to Solid-State Chemistry, Cambridge University Press: New York, 2007.

(22) (a) Housecroft, C. E. Boranes and Metalloboranes: Structure,Bonding and Reactivity. Horwood, E. Chichester; Halsted Press, New York, 1990. (b) Yan, H.; Beatty, A. M.; Fehlner, T. P. Reactivity of Dimetallapentaboranes—nido- $\left[\mathrm{CpM}_{2} \mathrm{~B}_{3} \mathrm{H}_{7}\right]$ —with Alkynes: Insertion to Form a Ruthenacarborane $(\mathrm{M}=\mathrm{RuH})$ versus Catalytic Cyclotrimerization to Form Arenes $(\mathrm{M}=\mathrm{Rh})$. Angew. Chem. Int. Ed. 2001, 40, 4498-4501. (c) Bose,S. K.; Geetharani, K.; Ghosh, S. C-H activation of arenes and heteroarenes by early transition metallaborane, $\left[(\mathrm{Cp} * \mathrm{Ta})_{2} \mathrm{~B}_{5} \mathrm{H}_{11}\right](\mathrm{Cp} *=$ $\eta^{5}-\mathrm{C}_{5} \mathrm{Me}_{5}$ ). Chem. Commun. 2011, 47, 11996-11998. (d) Geetharani, K.; Tussupbayev, S.; Borowka, J.; Holthausen, M. C.; Ghosh, S. A Mechanistic Study of the Utilization of arachnoDiruthenaborane $\left[(\mathrm{Cp} * \mathrm{RuCO})_{2} \mathrm{~B}_{2} \mathrm{H}_{6}\right]$ as an Active Alkyne-Cyclotrimerization Catalyst. Chem. Eur. J. 2012, 18, 8482-8489. (e) Álvarez, Á.; Macías, R.; Bould, J.; Fabra, M. J.; Lahoz, F. J.; Oro, L. A. Alkene Hydrogenation on an 11-Vertex Rhodathiaborane with Full Cluster Participation. J. Am. Chem. Soc. 2008, 130, 11455-11466.

(23) (a) Wade, K. The structural significance of the number of skeletal bonding electron-pairs in carboranes, the higher boranes and borane anions, and various transition-metal carbonyl cluster compounds. J. Chem. Soc. D, Chem. Commun. 1971, 0, 792-793; (b) Wade, K. Structural and Bonding Patterns in Cluster Chemistry. Adv. Inorg. Chem. Radiochem. 1976, 18, 1-66. (d) Fox, M. A.; Wade, K. Evolving patterns in boron cluster chemistry. Pure Appl. Chem. 2003, 75, 1315-1323. 
(24) (a) Jemmis, E. D.; Balakrishnarajan, M. M.; Pancharatna, P. D. A Unifying ElectronCounting Rule for Macropolyhedral Boranes, Metallaboranes, and Metallocenes. J. Am. Chem. Soc. 2001, 123, 4313-4323. (b) Jemmis, E. D.; Balakrishnarajan, M. M.; Pancharatna, P. D. Electronic Requirements for Macropolyhedral Boranes. Chem. Rev. 2002, 102, 93-144.

(25) (a) Fehlner, T. P. Electron Deficient Boron and Carbon Clusters. Olah, G. A.; Wade, K.; Williams, R. E., Eds. Wiley, New York, 1991, pp. 287. (b) Kennedy, J. D. Disobedient Skeletons, The Borane, Carborane, Carbocation Continuum,. Casanova, J. Ed Wiley, New York, 1998, pp. 85. (c) Xie, Z. Advances in the chemistry of metallacarboranes of f-block elements. Coord. Chem. Rev. 2002, 231, 23-46.

(26) (a) Mondal, B.; Bag, R.; Ghosh, S. Combined Experimental and Theoretical Investigations of Group 6 Dimetallaboranes $\left[(\mathrm{Cp} * \mathrm{M})_{2} \mathrm{~B}_{4} \mathrm{H}_{10}\right](\mathrm{M}=\mathrm{Mo}$ and $\mathrm{W})$. Organometallics 2018, 37, 2419-2428. (b) Mondal, B.; Bag, R.; Bakthavachalam, K.; Varghese, B. Ghosh, S. Synthesis, Structures, and Characterization of Dimeric Neutral Dithiolato-Bridged Tungsten Complexes. Eur. J. Inorg. Chem. 2017, 5434-5441. (c) Mondal, B.; Bhattacharyya, M.; Varghese, B.; Ghosh, S. Hypo-electronic triple-decker sandwich complexes: synthesis and structural characterization of $\left[(\mathrm{Cp} * \mathrm{Mo})_{2}\left\{\mu-\eta^{6}: \eta^{6}-\mathrm{B}_{4} \mathrm{H}_{4} \mathrm{E}-\mathrm{Ru}(\mathrm{CO})_{3}\right\}\right](\mathrm{E}=\mathrm{S} \text {, Se, Te or Ru(CO) })_{3}$ and $\mathrm{Cp}^{*}=\eta^{5}-\mathrm{C}_{5} \mathrm{Me}_{5}$ ). Dalton Trans. 2016, 45, 10999-11007. (d) Mondal, B.; Mondal, B.; Pal, K.; Varghese, B.; Ghosh, S. An electron-poor di-molybdenum triple-deckerwith a puckered $\left[\mathrm{B}_{4} \mathrm{Ru}_{2}\right]$ bridging ring is an oblato-closo cluster. Chem. commun. 2015, 51, 3828-3831. (e) Thakur, A.; Chakrahari, K. K. V.; Mondal, B.; Ghosh, S. Novel Triple-Decker Sandwich Complex with a Six-Membered $\left[\mathrm{B}_{3} \mathrm{Co}_{2}\left(\mu_{4}-\mathrm{Te}\right)\right]$ Ring as the Middle Deck. Inorg. Chem. 2013, 52, 2262-2264. (f) Sahoo, S.; Reddy, K. H. K.; Dhayal, R. S.; Mobin, S. M.; Ramkumar, V.; Jemmis, E. D.; Ghosh, S. Chlorinated Hypoelectronic Dimetallaborane Clusters: Synthesis, 
Characterization, and Electronic Structures of $\left(\eta^{5}-\mathrm{C}_{5} \mathrm{Me}_{5} \mathrm{~W}\right){ }_{2} \mathrm{~B}_{5} \mathrm{H}_{n} \mathrm{Cl}_{m}(n=7, m=2$ and $n=8, m$ = 1). Inorg. Chem. 2009, 48, 6509-6516.

(27) Aldridge, S.; Shang, M.; Fehlner, T. P. Synthesis of Novel Molybdaboranes from $\left(\eta^{5}-\right.$ $\left.\mathrm{C}_{5} \mathrm{R}_{5}\right) \mathrm{MoCl}_{n}$ Precursors (R = H, Me; $n=1$, 2, 4). J. Am. Chem. Soc. 1998, 120, 2586-2598.

(28) Dhayal, R. S.; Sahoo, S.; Reddy, K. H. K.; Mobin, S. M.; Jemmis, E. D.; Ghosh, S. Vertex-Fused Metallaborane Clusters: Synthesis, Characterization and Electronic Structure of $\left[\left(n^{5}-\mathrm{C}_{5} \mathrm{Me}_{5} \mathrm{Mo}\right)_{3} \mathrm{MoB}_{9} \mathrm{H}_{18}\right]$. Inorg. Chem. 2010, 49, 900-904.

(29) (a) Snow, S. A.; Shimoi, M.; Ostler, C. D.; Thompson, B. K.; Kodama, G.; Parry, R. W. Metal complexes of the neutral borane adduct $\left(\mathrm{B}_{2} \mathrm{H}_{4} \cdot 2 \mathrm{P}\left(\mathrm{CH}_{3}\right)_{3}\right)$. Inorg. Chem. 1984, 23, 511-512. (b) Katoh, K.; Shimoi, M.; Ogino, H. Syntheses and structures of $\left[\mathrm{M}(\mathrm{CO})_{5}\left\{\mathrm{~B}_{2} \mathrm{H}_{4}\right.\right.$. cntdot.2P( $\left.\left.\left(\mathrm{CH}_{3}\right)_{3}\right\}\right]$ and $\left[\mathrm{M}(\mathrm{CO})_{4}\left\{\mathrm{~B}_{2} \mathrm{H}_{4} \cdot\right.\right.$ cntdot.2P($\left.\left.\left(\mathrm{CH}_{3}\right)_{3}\right\}\right]$ (M = chromium, molybdenum, tungsten). Inorg. Chem. 1992, 31, 670-675.

(30) (a) Bailey, W. I. Jr.; Chisholm, M. H.; Cotton, F. A.; Rankel, L. A. Reactions of metal-tometal multiple bonds. 4. .mu.-Acetylene-bis(cyclopentadienyl)tetracarbonyldimolybdenum compounds. Preparations, properties, structural characterizations, and dynamical solution behavior. J. Am. Chem. Soc. 1978, 100, 5764-5773. (b) Fleischmann, M.; Jones, J. S.; Balázs, G.; Gabbaï, F. P.; Scheer, M. Supramolecular adducts based on weak interactions between the trimeric Lewis acid complex (perfluoro-ortho-phenylene)mercury and polypnictogen complexes. Dalton Trans. 2016, 45, 13742-13749.

(31) Jun, C.-S.; Halet, J.-F.; Rheingold, A. L.; Fehlner, T. P. Preparation and Characterization of Cobaltaboranes Containing Cobalt Carbonyl Fragments. Inorg. Chem. 1995, 34, 2101-2107. 
(32) Total skeletal electron pair (sep) of 2 is 6 and total valence electron (tve) is 40 .

(33) (a) Mingos, D. M. P. A General Theory for Cluster and Ring Compounds of the Main Group and Transition Elements. Nat. Phys. Sci. 1972, 236, 99-102. (b) Welch, A. J. The significance and impact of Wade's rules. Chem. Commun. 2013, 49, 3615-3616.

(34) Aldridge, S.; Fehlner, T. P.; Shang, M. Directed Synthesis of Chromium and Molybdenum Metallaborane Clusters. Preparation and Characterization of $(\mathrm{Cp} * \mathrm{Cr})_{2} \mathrm{~B}_{5} \mathrm{H}_{9}$, (Cp*Mo $)_{2} \mathrm{~B}_{5} \mathrm{H}_{9}$, and $(\mathrm{Cp} * \mathrm{MoCl})_{2} \mathrm{~B}_{4} \mathrm{H}_{10}$. J. Am. Chem. Soc. 1997, 119, 2339-2340.

(35) Weller, A. S.; Shang, M.; Fehlner, T. P. Synthesis of Mono- and Ditungstaboranes from Reaction of $\mathrm{Cp}^{*} \mathrm{WCl}_{4}$ and $\left[\mathrm{Cp}^{*} \mathrm{WCl}_{2}\right]_{2}$ with $\mathrm{BH}_{3} \cdot$ thf or $\mathrm{LiBH}_{4}\left(\mathrm{Cp}^{*}=\eta^{5}-\mathrm{C}_{5} \mathrm{Me}_{5}\right)$. Control of Reaction Pathway by Choice of Monoboron Reagent and Oxidation State of Metal Center. Organometallics 1999, 18, 53-64.

(36) Computed ${ }^{11} \mathrm{~B}$ NMR chemical shifts (for 3 ' and 5', the Cp analogues of 3 and 4) employing GIAO method satisfactorily helped us to assign all the boron atoms with a margin of error 10 ppm, whereas, for 5' (the Cp analogue of 5) ca. 40 ppm error was observed (see Table S1).

(37) Lei, X.; Shang, M.; Fehlner, T. P. 2,2'-commo-Bis[2-ruthena-nido-1-( cyclopentadienyl)ruthenahexaborane(12)]: An Unusual Ruthenaborane Related to Ruthenocene and Exhibiting a Linear Triruthenium Fragment. Angew. Chem. Int. Ed. 1999, 38, 1986-1989.

(38) (a) Corbett, J. D. Extended metal-metal bonding in halides of the early transition metals. Acc. Chem. Res. 1981, 14, 239-246. (b) Kennedy, J. D. The Polyhedral Metallaboranes Part I. Metallaborane Clusters with Seven Vertices and Fewer. Prog. Inorg. Chem. 1984, 32, 519-679. 
(c) Kennedy, J. D. The Polyhedral Metallaboranes Part II. Metallaborane Clusters with Eight Vertices and More. Prog. Inorg. Chem. 1986, 34, 211-434. (d) Ghosh, S.; Fehlner, T. P.; Noll, B. C. Condensed metallaborane clusters: synthesis and structure of $\mathrm{Fe}_{2}(\mathrm{CO})_{6}\left(\eta^{5}-\mathrm{C}_{5} \mathrm{Me}_{5} \mathrm{RuCO}\right)\left(\eta^{5}-\right.$ $\left.\mathrm{C}_{5} \mathrm{Me}_{5} \mathrm{Ru}\right) \mathrm{B}_{6} \mathrm{H}_{10}$. Chem. Commun. 2005, 3080-3082. (e) Wong, K.-S.; Bowser, J. R.; Pipal, J. R.; Grimes, R. N. Tetracarbon metallocarboranes. 5. A new synthetic route: synthesis of $\mathrm{Co}_{2} \mathrm{C}_{4} \mathrm{~B}_{6}$ and $\mathrm{CoC}_{4} \mathrm{~B}_{7}$ nido cage systems by fusion of dicarbon cobaltacarboranes in ethanolic potassium hydroxide. Crystal structure of $\left(\eta^{5}-\mathrm{C}_{5} \mathrm{H}_{5}\right)_{2} \mathrm{Co}_{2} \mathrm{C}_{4} \mathrm{~B}_{6} \mathrm{H}_{10}$. J. Am. Chem. Soc. 1978, 100, 5045-5051. (f) Mingos, D. M. P. Polyhedral skeletal electron pair approach. Acc. Chem. Res. 1984, 17, 311319. (g) Grimes, R. N. Cluster forming and cage fusion in metallacarborane chemistry. Coord. Chem. Rev. 1995, 143, 71-96. (h) Kennedy, J. D. In Advances in Boron Chemistry; Siebert, W., Ed.; Royal Society of Chemistry: Cambridge, U. K., 1997, pp 451.

(39) This can be explained qualitatively as; W3 is in bonding contact with W1, W2, B4 and two hydride ligands that contributes total of 5 electrons which is equal to that of a $\eta 5-\mathrm{Cp}$ or $\mathrm{Cp} *$ ligand. Molecular orbital calculation together with NBO analysis further supports the same.

(a) Wang, Y.; Quillian, B.; Wei, P.; Wannere, C. S.; Xie, Y.; King, R. B.; Schaefer, H. F. III; Schleyer, P. v. R.; Robinson, G. H. A Stable Neutral Diborene Containing a B=B Double Bond. J. Am. Chem. Soc. 2007, 129, 12412-12413. (b) Scheschkewitz, D. A Base-Stabilized Neutral B=B Bond: Closing a Gap by Filling the Void. Angew. Chem. Int. Ed. 2008, 47, 19951997. (c) Wang, Y.; Quillian, B.; Wei, P.; Xie, Y.; Wannere, C. S.; King, R. B.; Schaefer, H. F. III; Schleyer, P. v. R.; Robinson, G. H. Planar, Twisted, and Trans-Bent: Conformational Flexibility of Neutral Diborenes. J. Am. Chem. Soc. 2008, 130, 3298-3299. (d) Wang, Y.; Robinson, G. H. Carbene Stabilization of Highly Reactive Main-Group Molecules. Inorg. Chem. 
2011, 50, 12326-12337. (e) Wang, Y.; Robinson, G. H. N-Heterocyclic Carbene-Main-Group Chemistry: A Rapidly Evolving Field. Inorg. Chem. 2014, 53, 11815-11832.

(41) (a) Mitoraj, M. P.; Michalak, A. Multiple Boron-Boron Bonds in Neutral Molecules: An Insight from the Extended Transition State Method and the Natural Orbitals for Chemical Valence Scheme. Inorg. Chem. 2011, 50, 2168-2174. (b) Braunschweig, H.; Dewhurst, R. D. Single, Double, Triple Bonds and Chains: The Formation of Electron-Precise B-B Bonds. Angew. Chem. Int. Ed. 2013, 52, 3574- 3583. (c) Braunschweig, H.; Dewhurst, R. D. BoronBoron Multiple Bonding: From Charged to Neutral and Back Again. Organometallics 2014, 33, 6271-6277. (d) Brand, J.; Braunschweig, H.; Sen, S. S. B=B and B $\equiv E(E=N$ and O) Multiple Bonds in the Coordination Sphere of Late Transition Metals. Acc. Chem. Res. 2014, 47, 180191. (e) Fischer, R. C.; Power, P. P. $\pi$-Bonding and the Lone Pair Effect in Multiple Bonds Involving Heavier Main Group Elements: Developments in the New Millennium. Chem. Rev. 2010, 110, 3877-3923. (f) Power, P. P. Interaction of Multiple Bonded and Unsaturated Heavier Main Group Compounds with Hydrogen, Ammonia, Olefins, and Related Molecules. Acc. Chem. Res. 2011, 44, 627-637.

(42) (a) Hashimoto, H.; Shang, M.; Fehlner, T. P. Clusters as Ligands. Coordination of an Electronically Unsaturated Chromaborane to an Iron Tricarbonyl Fragment. J. Am. Chem. Soc. 1996, 118, 8164-8165. (b) Aldridge, S.; Hashimoto, H.; Kawamura, K.; Shang, M.; Fehlner, T. P. Cluster Expansion Reactions of Group 6 Metallaboranes. Syntheses, Crystal Structures, and Spectroscopic Characterizations of $\left(\mathrm{Cp} * \mathrm{Cr}_{2}\right)_{2} \mathrm{~B}_{5} \mathrm{H}_{9}, \quad(\mathrm{Cp} * \mathrm{Cr})_{2} \mathrm{~B}_{4} \mathrm{H}_{8} \mathrm{Fe}(\mathrm{CO})_{3}, \quad(\mathrm{Cp} * \mathrm{Cr})_{2} \mathrm{~B}_{4} \mathrm{H}_{7} \mathrm{Co}$ $(\mathrm{CO})_{3}$, and $(\mathrm{Cp} * \mathrm{Mo})_{2} \mathrm{~B}_{5} \mathrm{H}_{9} \mathrm{Fe}(\mathrm{CO})_{3}$. Inorg. Chem. 1998, 37, 928-940. 
(43) The asymmetric unit of 7 contains four independent molecules which differ little in terms of geometric parameters. As a result, the structural data presented in Figure 6 (a) is from one of the units.

(44) (a) Handy, L. B.; Ruff, J. K.; Dahl, L. F. Structural characterization of the dinuclear metal carbonyl anions $\left[\mathrm{M}_{2}(\mathrm{CO})_{10}\right]^{2-}(\mathrm{M}=$ chromium, molybdenum $)$ and $\left[\mathrm{Cr}_{2}(\mathrm{CO})_{10} \mathrm{H}\right]^{-}$. Marked stereochemical effect of a linearly protonated metal-metal bond. J. Am. Chem. Soc. 1970, 92, 7312-7326. (b) Scherer, O. J.; Sitzmann, H.; Wolmershäuser, G. Umsetzung von $\mathrm{P}_{4}$ mit ( $\eta^{5}$ $\left.\mathrm{C}_{5} \mathrm{H}_{5}\right)(\mathrm{CO})_{2} \mathrm{Mo} \equiv \mathrm{Mo}(\mathrm{CO})_{2}\left(\eta^{5}-\mathrm{C}_{5} \mathrm{H}_{5}\right)$ zu den tetraedrischen molybdänkomplexen $\mathrm{P}_{n}\left[\mathrm{Mo}(\mathrm{CO})_{2}\left(\eta^{5}-\right.\right.$ $\left.\left.\mathrm{C}_{5} \mathrm{H}_{5}\right)\right]_{4^{-} n}(n=2,3)$. J. Organomet. Chem. 1984, 268, C9-C12.

(45) (a) Dahyal, R. S.; Sahoo, S.; Ramkumar, V.; Ghosh, S. Substitution at boron in molybdaborane frameworks: Synthesis and characterization of isomeric $\left(\eta^{5}-\mathrm{C}_{5} \mathrm{Me}_{5} \mathrm{Mo}\right)_{2} \mathrm{~B}_{5} \mathrm{H}_{n} \mathrm{X}_{m}$ (when $\mathrm{X}=\mathrm{Cl}: n=5,7,8 ; m=4,2,1$ and $\mathrm{X}=\mathrm{Me}: n=6,7 ; m=3,2$ ). J. Organomet. Chem. 2009, 694,

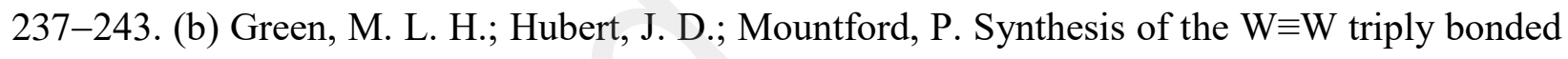
dimers $\left[\mathrm{W}_{2}\left(\eta^{5}-\mathrm{C}_{5} \mathrm{H}_{4} \mathrm{R}\right)_{2} \mathrm{X}_{4}\right](\mathrm{X}=\mathrm{Cl}, \mathrm{R}=\mathrm{Me}$ or Pri; $\mathrm{X}=\mathrm{Br}, \mathrm{R}=$ Pri $)$ and $\mathrm{X}$-ray crystal structures of $\left[\mathrm{W}\left(\eta^{5}-\mathrm{C}_{5} \mathrm{H}_{4} \mathrm{Pri}\right) \mathrm{Cl}_{4}\right]$ and $\left[\mathrm{W}_{2}\left(\eta-\mathrm{C}_{5} \mathrm{H}_{4} \mathrm{Pri}\right)_{2} \mathrm{Cl}_{4}\right]$. J. Chem. Soc. Dalton Trans. 1990, 3793-3800. (c) Kaushika, M.; Singh, A.; Kumar, M. The chemistry of group-VIb metal carbonyls. Eur. J. Chem. 2012, 3, 367-394.

(46) Ryschkewitsch, G. E.; Nainan, K. C. Octahydrotriborate(1-) $\left[\mathrm{B}_{3} \mathrm{H}_{8}\right]$ salt. Inorg. Synth. 1974, 15, 113-114.

(47) Gaussian 09, Frisch, M. J. et al., Gaussian, Inc., Wallingford CT, 2010 (for detailed reference see supporting information). 
(48) (a) Schmider, H. L.; Becke, A. D. Optimized density functionals from the extended G2 test set. J. Chem. Phys. 1998, 108, 9624-9631. (b) Perdew, J. P. Density-functional approximation for the correlation energy of the inhomogeneous electron gas. Phys. Rev. B 1986, 33, 8822-8824.

(49) Weigend, F.; Ahlrichs, R. Balanced basis sets of split valence, triple zeta valence and quadruple zeta valence quality for H to Rn: Design and assessment of accuracy. Phys. Chem. Chem. Phys. 2005, 7, 3297-3305.

(50) Andrae, D.; Häußermann, U.; Dolg, M.; Stoll, H.; Preuss, H. Energy-adjustedab initio pseudopotentials for the second and third row transition elements. Theor. Chim. Acta. 1990, 77, $123-141$.

(51) (a) Becke, A. D. Density-functional exchange-energy approximation with correct asymptotic behavior. Phys. Rev. A 1988, 38, 3098-3100. (b) Lee, C.; Yang, W.; Parr, R. G. Development of the Colle-Salvetti correlation-energy formula into a functional of the electron density. Phys. Rev. B 1988, 37, 785-789. (c) Becke, A. D. Density-functional thermochemistry. III. The role of exact exchange. J. Chem. Phys. 1993, 98, 5648-5651.

(52) (a) London, F. Théorie quantique des courants interatomiques dans les combinaisons aromatiques. J. Phys. Radium. 1937, 8, 397-409. (b) Ditchfield, R. Self-consistent perturbation theory of diamagnetism. Mol. Phys. 1974, 27, 789-807. (c) Wolinski, K.; Hinton, J. F.; Pulay, P. Efficient implementation of the gauge-independent atomic orbital method for NMR chemical shift calculations. J. Am. Chem. Soc. 1990, 112, 8251-8260.

(53) (a) Glendening, E. D.; Reed, A. E.; Carpenter, J. E.; Weinhold, F. NBO Program 3.1, W. T. Madison: 1988; (b) Reed, A. E.; Weinhold, F.; Curtiss, L. A. Intermolecular interactions from 
a natural bond orbital, donor-acceptor viewpoint. Chem. Rev. 1988, 88, 899-926. (c) Weinhold, F.; Landis, R. Valency and bonding: A natural bond orbital donor-acceptor perspective. Cambridge University Press: Cambridge; U.K, 2005.

(54) Wiberg, K. B. Application of the pople-santry-segal CNDO method to the cyclopropylcarbinyl and cyclobutyl cation and to bicyclobutane. Tetrahedron 1968, 24, 1083-1096.

(55) (a) Bader, R. F. W. Atoms in Molecules: a Quantum Theory; Oxford University Press: Oxford, U. K. 1990. (b) Bader, R. F. W. A Bond Path: A Universal Indicator of Bonded Interactions. J. Phys. Chem. A. 1998, 102, 7314-7323. (c) Bader, R. F. W. A quantum theory of molecular structure and its applications. Chem. Rev. 1991, 91, 893-928.

(56) Lu, T.; Chen, F. Multiwfn: A multifunctional wavefunction analyzer. J. Comput. Chem. 2012, 33, 580-592.

(57) Bruker (2004). APEX2, SAINT and SADABS. Bruker AXS Inc., Madison, Wisconsin, USA.

(58) Sheldrick, G. M. SHELXS-97; University of Göttingen (Germany), 1997.

(59) Sheldrick, G. M. Crystal structure refinement with SHELXL. Acta Cryst. 2015, C71, 3-8. 


\section{For Table of Contents Only}

Use of Single Metal Fragments for Cluster Building: Synthesis, Structure and Bonding of

\section{Heterometallaboranes}

Using CO gas we have synthesized an extremely fluxional molybdenum diborane(4) species, $\left[\left\{\mathrm{Cp} * \mathrm{Mo}(\mathrm{CO})_{2}\right\}_{2}\left\{\mu-\eta^{2}: \eta^{2}-\mathrm{B}_{2} \mathrm{H}_{4}\right\}\right]$ that mimic Cotton's dimolybdenum-acetylene complex, $\left[\left\{\mathrm{CpMo}(\mathrm{CO})_{2}\right\}_{2} \mathrm{C}_{2} \mathrm{H}_{2}\right]$. In addition, we have isolated and structurally characterized a homoleptic molybdaborane, $\left[(\mathrm{Cp} * \mathrm{Mo})_{3}(\mu-\mathrm{H})_{2}\left(\mu_{3}-\mathrm{H}\right)(\mu-\mathrm{CO})_{2} \mathrm{~B}_{4} \mathrm{H}_{4}\right]$, and a vertex-fused cluster, $\left[(\mathrm{Cp} * \mathrm{~W})_{3}\right.$ $\left.\mathrm{WB}_{9} \mathrm{H}_{18}\right]$ (see picture). 